\title{
Ethnoastronomical Perspectives on Saami Religion
}

\author{
BY Bo SOMMARSTRÖM
}

\begin{abstract}
... language is not (as is commonly thought) a system for transferring thoughts or meaning from one brain to another, but a system for organizing information and for releasing thoughts and responses in other organisms. The materials for whatever insights there are in this world exist in incipient form, frequently unformulated but nevertheless already there in man. One may help to release them in a variety of ways, but it is impossible to plant them in the minds of others. Experience does that for us instead-particularly overseas experience.
\end{abstract}

With these words of Edward T. Hall (Hall 1977, 57) I should like to stress the difficulty facing any scholar trying to interpret information given by Saamis about the pictures on some of their shaman drums (of which only some seventy have been preserved). Louise Bäckman has summarized the problems by emphasizing that "the Lapps found themselves in an emergency situation and in a time of upheaval" when they were asked for explanations of the drum pictures: "it is almost impossible for posterity to decide whether the answers really covered the ideas" (Bäckman 1975, $38 \mathrm{ff.,} \mathrm{143).}$ A number of the pictures seem to give expression to a synchretistic religion with features of Christianity (God, churches, priests, crosses) mixed with inherited Nordic and Saami aspects but these may also be seen as calculated elements in conformity with the extant pictures of secular authorities. Bo Lundmark, in his thesis on the Saamis' concepts of the heavenly bodies-in spite of his awareness of the difficulties mentioned, has nevertheless managed to extract much that is new with the help inter alia of the drum pictures, thanks to the fact that he patiently and critically weighed the scanty and unreliable explanations of the pictures against other richer source material (Lundmark 1982, 39-46). In this context he has used statistical methods to support certain hypotheses, such as the one that the boat-like motif on the drums is connected with Saami offerings in birchbark boats at Christmas time and more generally with the moon cult. Particularly interesting from my point of view is the fact that he also thinks in terms of positioning, i.e. emphasizing how significant it is that this boat symbol "occurs almost without exception [...] on the upper field of the drum", which is important since "this positioning coincides remarkably clearly with the symbol of the moon on the drums where this is represent- 
ed" (Lundmark 1982, 73). But unfortunately this material is still scanty and unreliable in terms of source criticism, as has been strongly emphasized by another recent Swedish scholar of Saami religion with his comment "Pictures without comment from the artist are fragile material, which can easily lead the interpreter dangerously astray', an attitude that acquires particular force in that the statement is preceded by an unusually thorough and comprehensive review of the source material (Mebius 1968, 13).

Aware of these underlying difficulties in interpreting the pictures on the Saami shaman drums I have nonetheless tried to make progress, partly by extending the material to include the humble "handle drums" (Sommarström 1965; Sommarström 1969), partly by a phenomenological study of material comparable to the rhomb- cross sign of the sun on most of these drums (Sommarström 1967), and most recently (Sommarström 1985) through a preliminary account of my observation that at least some of the figures found in the space between the central sun sign and the edge on some fifty drumskins occupy positions within certain quadrants like similar figures in our traditional western star charts.

The present study continues the theme of the last named article by making a similar comparison of the pictures on the edge and the central figure complex (the sun sign). As the analysis has been extended, it has also become possible to adopt a new position with regard to the overall picture. This has led to observations that the zodiac can be discerned more or less clearly in the mass of constellations, that the positioning is decided by orientating the drum in relation to the height of the sun and thus to the Saamis' calendar, to the seasons and to the cardinal points. It is moreover probable that the drums were connected, at least indirectly, to a commonly held idea about the natural elements and their connection with people's basic temperaments. In other words: the similarity between the Saamis' "magic drums" and the astrolabes found among the European neighbouring peoples has in my opinion been further reinforced, provided one means by this the basic pattern of the figures and their arrangement in a holistic system which we could regard as a psycho-cosmogram. It is even possible that the Saami shaman, noai' de, if he peered from underneath, through the semitransparent drumskin, could understand the horoscope diagram with its reversed constellations/signs as was used by his colleagues in the rest of Europe-as a theistically sanctioned cosmological projection, in contrast to the natural reproduction by the Saami drum of the apparent anti-clockwise rotation of the stars once every twenty-four hours.

As in the immediately previous article I must once again stop at a preliminary account of my analysis designed to show that the ethnoastronomical principle may be a justifiable assumption. 


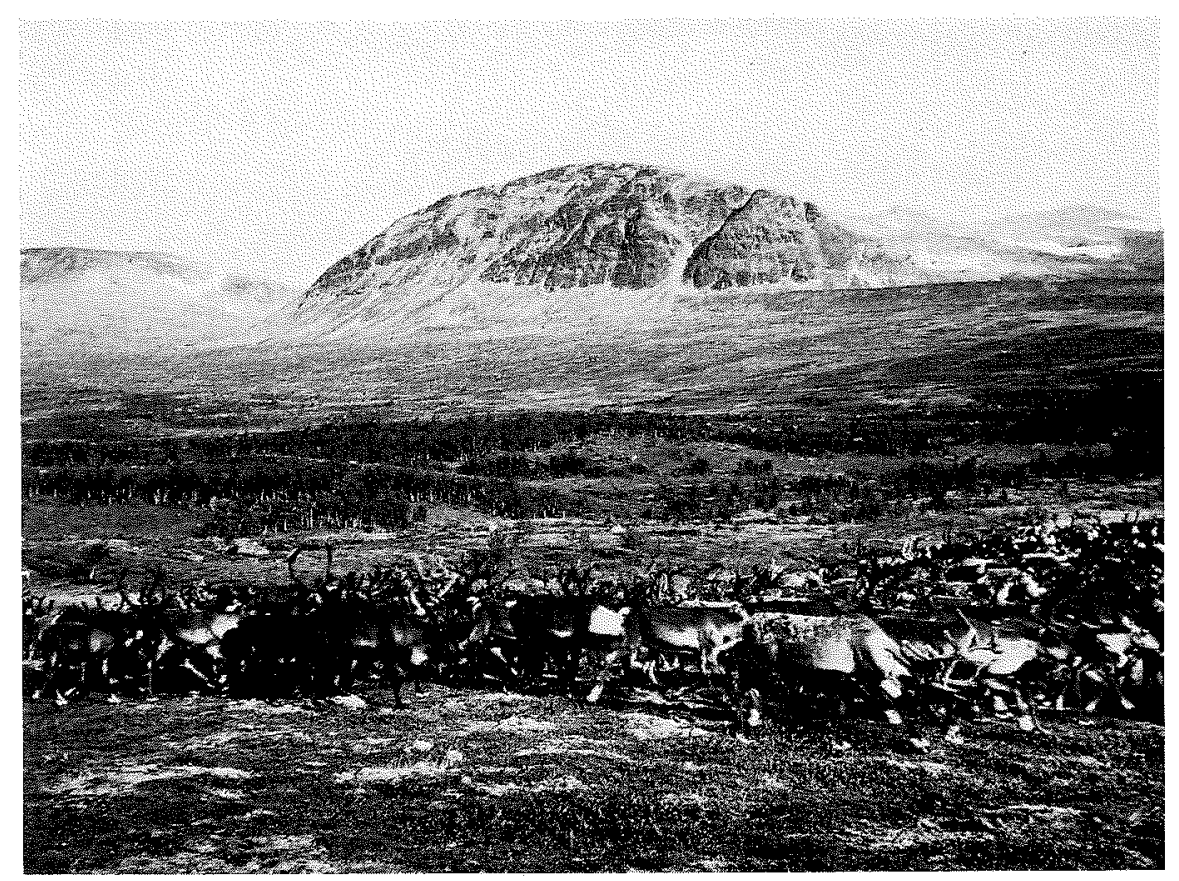

Fig. 1. GUOB'DÁBÁK'TE, precipice named after the bowlshaped type of divination drum ( $g u o b^{\prime} d a ́$, here turned upside-down). It is situated on a mountain ridge between the Small Lule and the Pite rivers in the middle of Swedish Lapland. In front of it is Parka, a large reindeer herders' spring-and autumn (now also summer) camping ground for several herding units $\left(s i i^{\prime} d a\right.$ ). The last known shaman connected with this place was probably "Unnatj", whose real name was Pehr Olofsson Kukkuk (1770-1858). He made offerings on the top of the precipice. His drum is said to have been hidden in the crevice which is $\mathrm{Y}$-shaped like the regular drumstick used by the Saamis; a pendant from this drum is said to have been found here (Pirak 1937, 167ff.). Lars Pirak, personal communication, 1986.) - This elevated place must have been a suitable point of departure for trance journeys to the $U p p e r$ Worlds, for the benefit of the many families gathering here in ordinary reality. (Author's photo.)

The prerequisite is a willingness to accept, that this may be one of many natural acculturation phenomena arising from contacts between the Saamis and their neighbours among the Nordic peoples, which at the time when the magic drums were collected (the 17 th and 18 th centuries) became greatly intensified for fiscal reasons and because of increased political interest in the Arctic area. Many details of the research data are still unclear and can doubtless be interpreted more successfully than I have managed, as anyone 


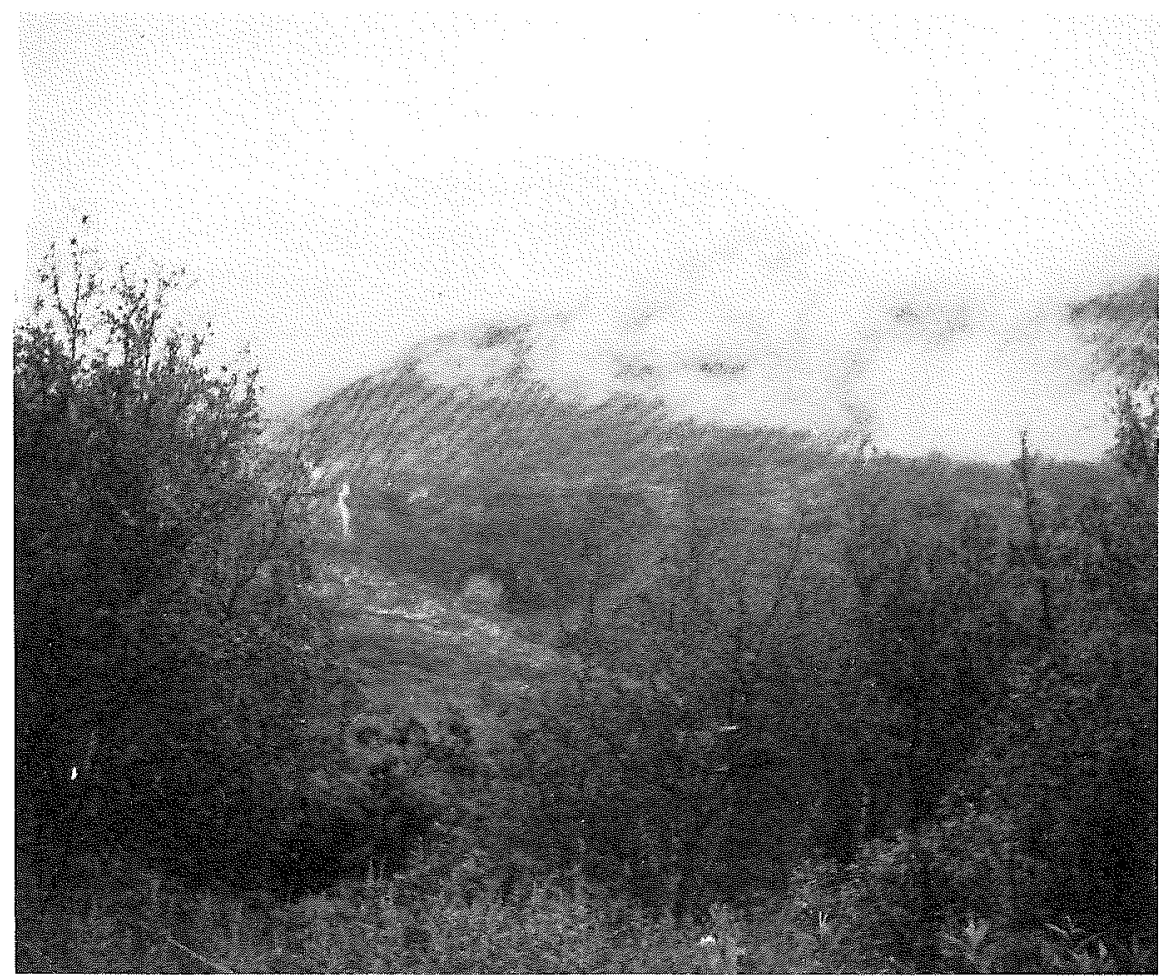

Fig. 2. BASSEUK'SA, "Holy Doorway", or GANIIUK'SA, "Spirit Doorway" as this $25 \mathrm{~m}$ wide cave entrance was called in olden times, is one of the most renowned sacred places of the Saami people. In the 17th century Saamis described the principal deity here as being a stone in the shape of a "large bird"; it is not known whether it was placed in this cavity, or below in a small cave where also other siei'de stones were offered to in later times with fat, bones and antlers of reindeer. A certain Biei've ("Sun") Niila, who may have been contemporary with the aforenamed Unnatj, also used to go to the left side of the opening and there whirl a bull-roarer around his head; the sound was "similar to bird wings" and returned as an echoe "after two hours" from the unknown depths of the interior (Lars Pirak, personal communication 1986; a relative of his has inherited the instrument). Maybe it was the gadnihah (sing. ganii), "the small people below", who gave the answers to Niila's questions. The precipice here is dangerous for men and reindeer who seasonally migrate along the Small Lule river. - The offerings and divinations here halfway up the Tarrekaise mountain seem to have been of a rather mundane character-rites de passage at a hole for shamanic journeys in the Middle Worlds where spirits appear close to the surface. (Author's photo.) 


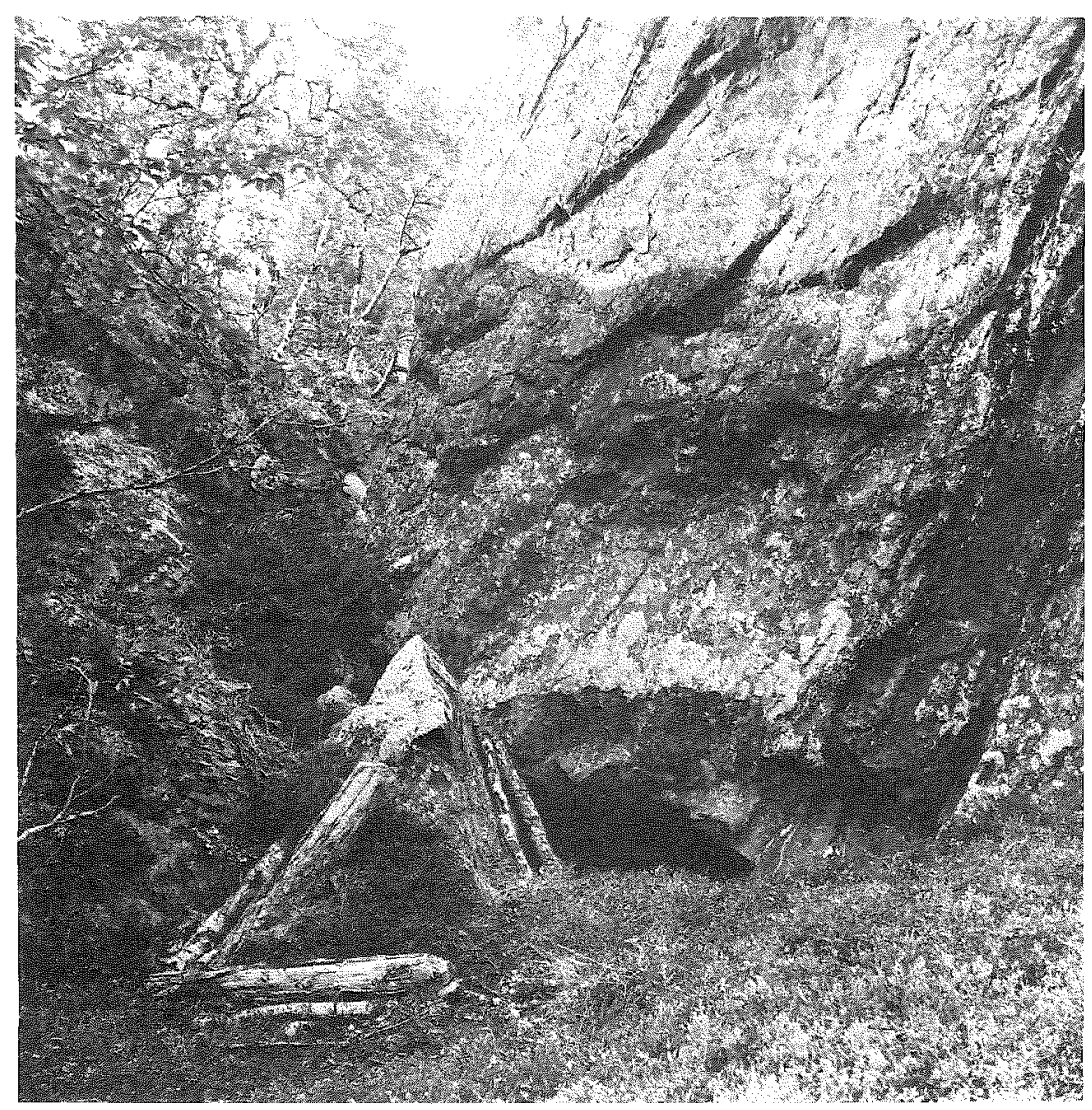

Fig. 3. LÁHPE-GIER'GE, cracked stone containing a den, between the lakes of Tjeggelvas and Faleshaure in the Upper Pite river. The opening is only $55 \mathrm{~cm}$ high and inside is a hearth of stones. This den could have been used by "Spiro junior", a rich and parsimonious reindeer herder who moved between this region and Balvand in Norway around the beginning of this century. Hundred years before another rich reindeer herder, Liuta, and his wife used spirits shaped like baer'jasah (cloth pieces for smoke-openings of tents) to keep their herd together (Pirak 1937, $174 \mathrm{ff}$.; Lars Ranberg, about the probably identical figure Liuko, personal communication, 1960). A personality more closely bound to the Tjeggelvas region was a great shaman called Anna Vuolla, who must have lived a very long time ago, as his or her skeleton (which is androgyne) is lying under rocks on a small islet and not buried in a churchyard. One of the sacred places in the vicinity consists of a cracked cliff which possibly has been used for magnifying sound waves, from a shaman's iron staff with rings found here. - A crack in the surface of the Earth would certainly be a good place from which to start spiritual journeys to the Underworlds. (Author's photo.) 


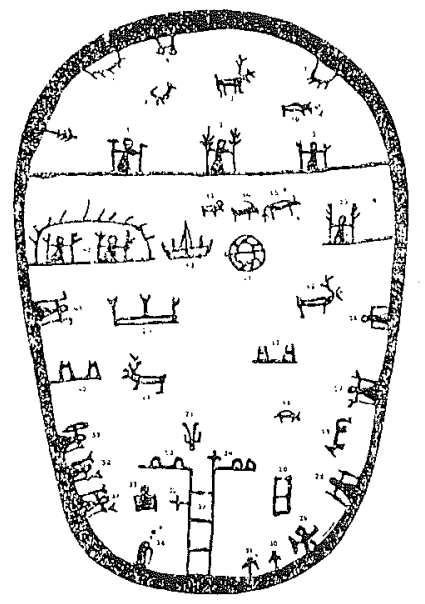

a b
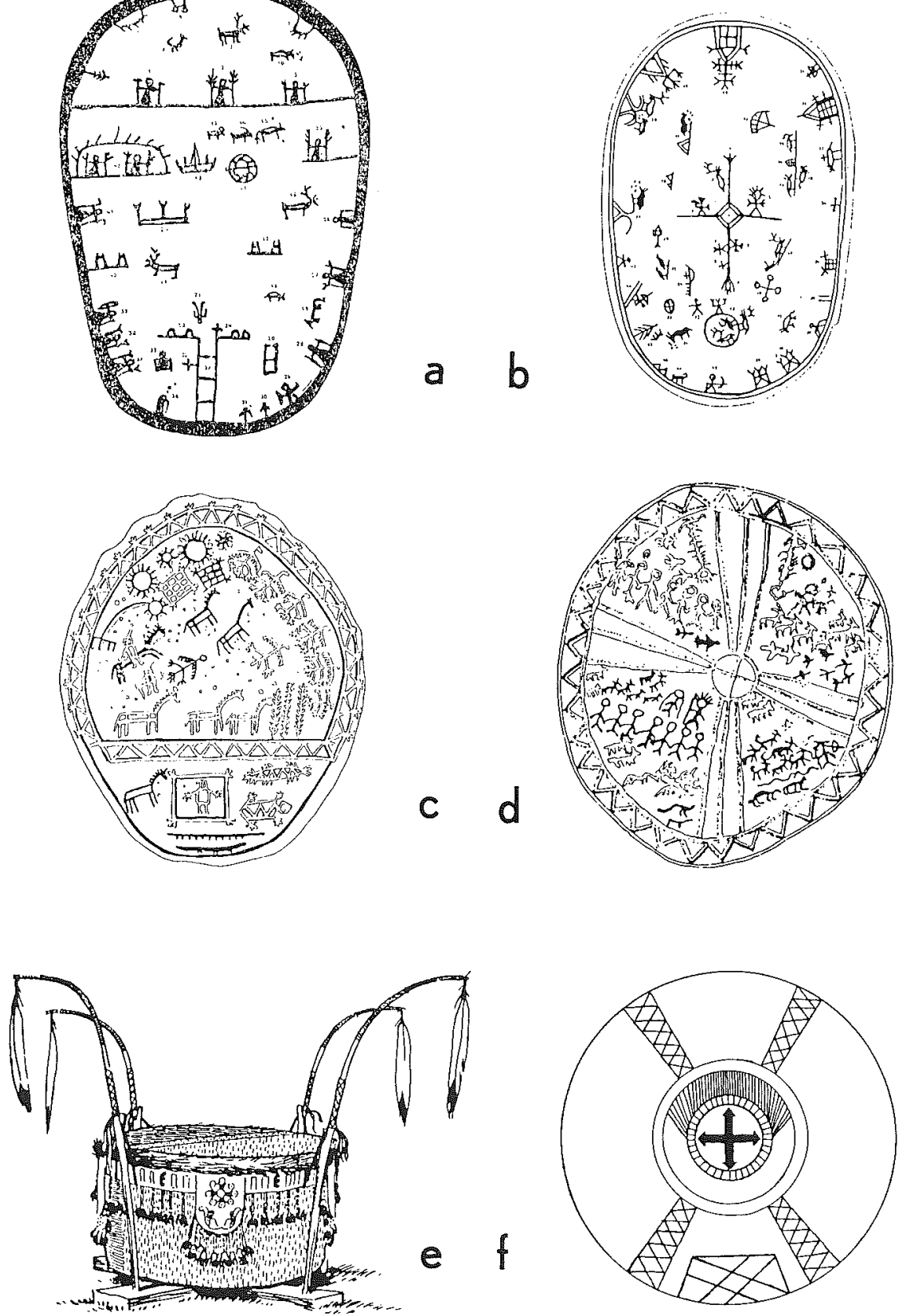

Fig. 4 


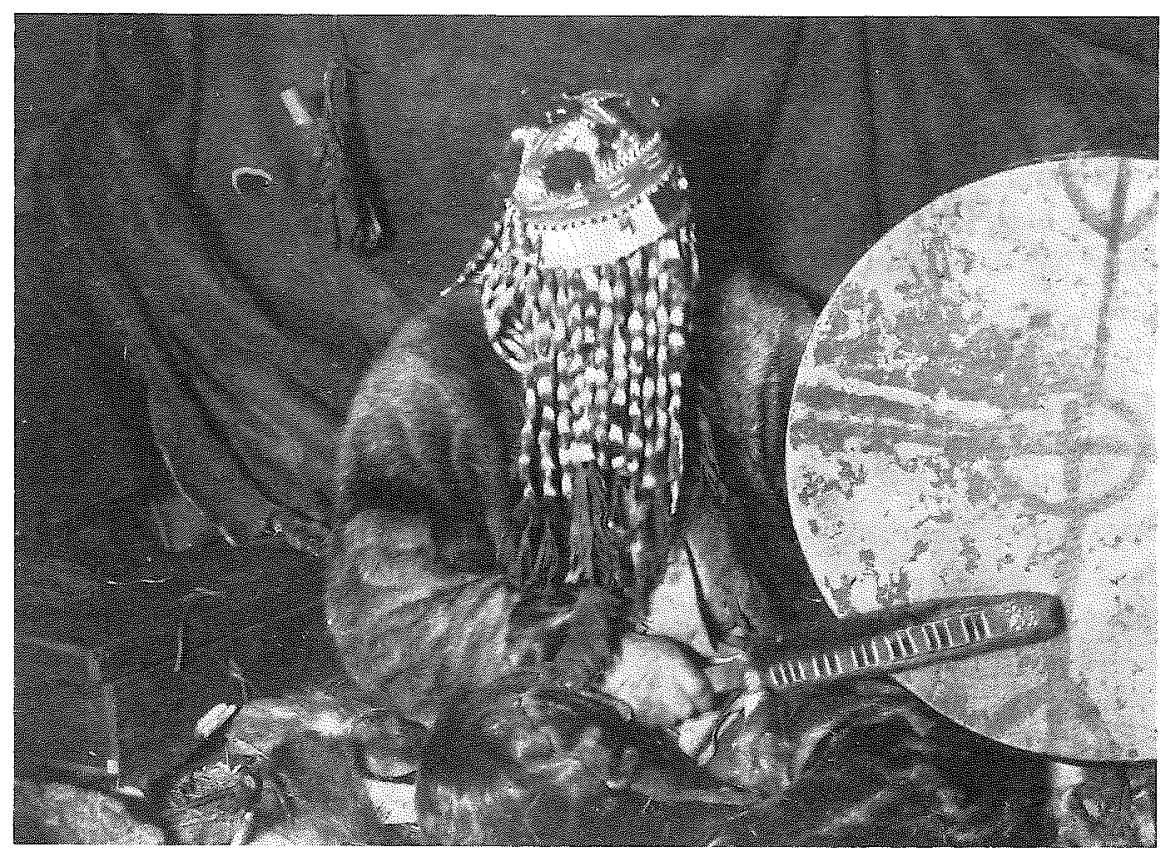

Fig. 5. Siberian shaman with his drum in a tent, photographed by the Swedish explorer Sten Bergman during a visit 1922 to the Tungusic Lamut people in Kamchatka, Eastern Siberia. Note the fringed headdress which is like a blindfold keeping his eyes shut off for facilitating the state of trance. In a similar way the Saami shamans could have used the $r a b^{\prime} d a$, a piece of cloth around their ordinary headdress, according to a note by $\mathrm{H}$. V. Rosendahl in connection with his purchase of a magical, drum-like instrument 1890 (cf. Sommarström 1965, 125; Sommarström 1969, 94). (Photo: The Ethnographical Museum of Sweden, Stockholm.)

Fig. 4. Vertical and horizontal projections of the "worlds" visited by shamans in states of trance. In order from top to bottom: Saami, Siberian and Indian drums. The left column shows the Upper, Middle and Lower realms, whereas the right one reflects the work of penetrating through the entrance to each of these major realms drumhead reproduced after Ivanov by Joan Halifax: Shaman. The Wounded Healer, shamanic journeys in general. ( $a-b$ after Manker 1950, drums 64 and 30; $c$ a Teleut drumhead reproduced after Ivanov by Joan Halifax, Halifax 1982, Fig. p. 35; $d$ a Beltir drum from Altai, after Ivanov, in Sommarström 1967, Fig. 2 b; $e$ the Chippewa Dream Dance Drum in hanger (always placed with the middle stripe going eastwest), after Mason 1938, Fig. p. 110; $f$ a Beaver Indian shaman's drum with "the world of four quarters and the two inner supernatural worlds", after Ridington \& Ridington 1970,52 , Fig. 1.) 
may see by applying my tentative model chart (Fig. 12) to the raw material, the 72 drumskins with pictures, of which 50 comprise the main object of this study.

One argument in support of the ethno-astronomical interpretation is that it must have been an advantage for the noai'de when he told the fortunes of other Nordic people (who had a great and all-embracing respect for his knowledge) to share a common frame of reference with them, the heliocentric cosmogony which became increasingly established during the 17 th century. This does not preclude other sorts of interpretations for the individual pictures but is concerned in principle only with the disposition of the picture surface, at least for some of the figures. In this light, one may easily compare expressions of synchretism between Christianity and other local religions and shamanistic concepts, for example the wool pictures of the present day Huichol Indians of Mexico (Negrin 1984; Hellbom 1984). In both cases the underlying visionary technique of the shaman is certainly not changed, but on the other hand changes are produced in the cosmological and religious system of ideas which he uses together with his "clients".

Neither does an ethnoastronomical explanatory model exclude a psychological hypothesis based, for example, on Jung's theory of archetypes (e.g. Mansfield 1981). This particular perspective is already embedded in the heart of astrology, not least in the classic astrological systems developed parallel with astronomy, which were gradually accepted by the Christian Church and used regularly in the immediate vicinity of the noai'des as late as the 17th century (e.g. Champeaux \& Sterckx 1966; or Kenton 1974, 19f.).

\section{The solar system on the drumskin}

If it is a correct interpretation that at least some of the figures which hover more or less freely between the centre and the edge of the 50 drums which have a round or (mostly) rhomb- cross sign in the middle represent constellations (Sommarström 1985), a natural follow-up question is whether the central figure is also astral, or represents the sun and the other planets. There are sufficient statements in the source material to confirm that the sign stands for the sun, Biei've, but unfortunately there are all too few explanations of the actual composition of the complex, which often comprises the true form: a rhombus (or in rare cases a circle) with normally cross shaped rays or arms to which are attached several anthropomorphic figures, reindeer or elks etc (Manker 1950).

The source material is of hardly any help at all in this respect. Randulf's interpretation is, in the light of our hypothesis the most interesting one for understanding the totality, and we therefore quote his description from 1723 
after Ernst Manker's translation in Die lappische Zaubertrommel: "Ist Paive oder die Sonne, welche sie, in Hinblick auf ihren Lauf rund um die 4 Teile der Welt sowohl als ein auf einer Ecke aufgestelltes als auch auf einem Hohlfuss stehendes Viereck abgebildet haben. Es geht ein Weg von der Erde [zur Sonne], um zu bezeichnen, dass ähnlich wie ihre Gebete auf der Erde diesen Weg entlang zur Sonne gehen, so auch das Licht, die Wärme und Fruchtbarkeit diesen Weg entlang hinunter zur Erde kommt, wenn Waralden Olmay oder Saturnus das zulässt. Insbesondere beten sie die Sonne an, wenn sie entweder auf der See sind, wie es die See-Lappen zu tun pflegen, und die Sonne untergeht, oder wenn sie allein, weit weg von den anderen im Hochgebirge sind und es dunkel wird, so dass sie nicht mehr sehen und den Weg zu ihren Rentieren oder Koten finden können. Dann fallen sie auf die Knie und bitten die Sonne um ihr Licht, und versprechen der Sonne ein Opfer, wenn sie ihnen helfen will, welches Versprechen sie auch unbedingt halten" (Manker 1950, 64).

This piece contains several noteworthy items of information of which I shall now only consider three. Firstly, the statement that the Saamis depicted the sun as square because of its (annual) course "round" the "4 continents" of the world; it is a view of the sun which is not merely the usual naturalistic one of the "planet"/the star "an sich", but rather a geometric symbol for its apparent cycle in relation to our earth. It is, in other words, identical amongst other things with the graphic representation found for example in the envelope-shaped horoscope picture occurring during the period in question (and incidentally right up to the 20th century), where the four corners of the rhombus indicate the four seasons or the intersections of the ecliptic seen in a time perspective (positions of the sun). The sides thus connect the "ascendent", the Medium Coeli, the "descendent" and the Immun Coeli to use the terminology of the astrologers. At the same time, however, Randulf speaks of the sun's more obvious properties of light, warmth and fertility, but the chronological aspect is the most prominent here and the one mentioned first. After this the relation of sun to earth is described as being dependent on Waralden Olmay, "the Lord of the World", who is also in this context equated with Saturn. But this planet god is not directly associated with the sign of the sun, and is not normally one of the figures on the latter, but stands outside. One cannot then, as a matter of course, see a resemblance to the envelope horoscopes, which are more schematically composed of 12 "houses" in the form of triangles shaped by the division of the basic rhombus into other quadrangles. For the shaman, however, the more important objects seem to have been moved towards the sign of the sun. Manker summarizes this in the following passage: "Die figuren auf den Strahlen des Sonnenzeichens weisen eine 
Reihe mythologischer Gestalten und Motive auf, die in dieser oder jener Hinsicht mit der Sonne in Zusammenhang gesetzt worden sind. Dazu gehören die Wettergottheiten Horagalles (Tiermes), das Gewitter, und Bieggolmai, der Wind, die Jagdgottheiten Leibolmai mit oder ohne Wild (dieses Jagdmotiv wird manchmal nur durch eine Elch- oder Renfigur dargestellt), die drei "Feiertagsmänner', Ailesolmak, usw." Lundmark has also dealt with this central sign in "The sun on the drum" and also adopts the view that these individual parts represent nature gods (Lundmark 1982, $39 \mathrm{ff}$.). For my own part I should like to add the observation that the figures have been grouped on the arms of the cross by category in the following manner: the two weather gods, Tor (Horagalles), who is responsible for very bad weather (thunder and lightning), together with Bieggolmai, who represents wind, rain and snow, that is the more "normal" types of weather, balance each other on the ends of the horizontal arm; the mysterious, hitherto unexplained holiday figures (literally either "holy" or "saints") are positioned on the lower end of the vertical arm and the hunting symbols on the upper end. By analogy with the first-named pair one could interpret these as a pair of opposites, "Sundays and weekdays", holiday and working day, protected by the "holyday men" and the hunting god, respectively.

The information about sun worship provided by Randulf in this context does not really have any direct connection with the utilization of the drum. On the other hand, one may posit a link here with other source data from Saami drum owners who claimed that they needed their drums to find their way home to their tents (Sommarström 1967, 146), that the drums were their "compasses". It is not easy to understand what they might have meant, but of the possible interpretations I should like to suggest the following. In the absence of ordinary landmarks (streams, long branches or anthills on the south side) out at sea or on the bare mountain or in rain, fog or snow, perhaps beating the drum could send the owner into such a trance that he became extra sensitive to a hidden sun-or starlight or other signs of nature. Another explanation lying near to hand would be that beating the drum was a form of communication with other Saamis, the instrument being used as a telegraph with a radius of several miles (as far as I know, there is no evidence at all of such a function, which is otherwise well known e.g. in Africa). A third possibility could have been to use the surface picture of the drum as a simple yet adequate astrolabe, which it resembles when one combines the signs of the zodiac and other constellations with indications of time and space: the hours of the day, the four cardinal points. I shall attempt below to make such an interpretation sound feasible, but I should first like to comment on the sign of the sun in another perspective. 


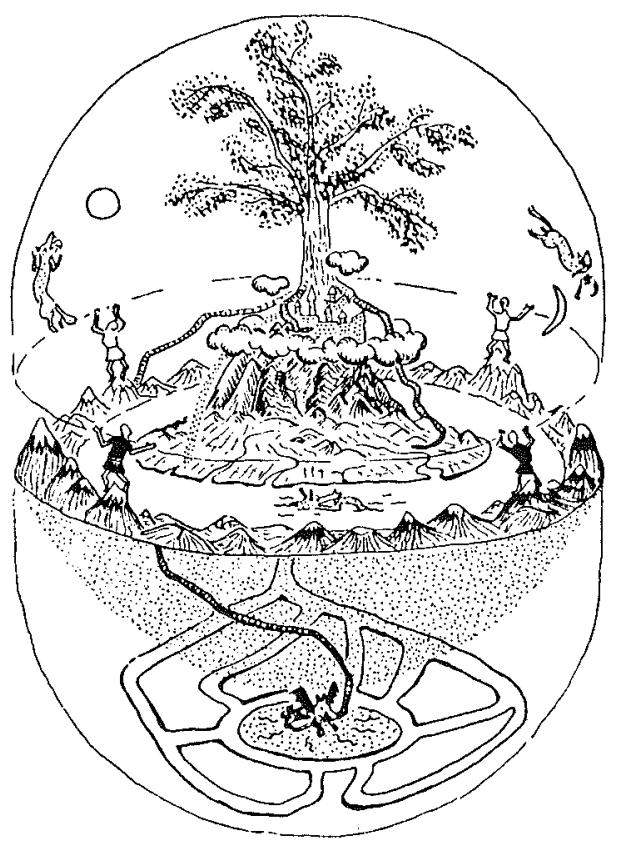

Fig. 6. YGGDRASIL, the old Nordic World Tree, an Ash. This symbol of the living Universe unifies the "worlds" of Asgard, Midgard and Niflheim, each with three sub-realms, thus nine worlds in all. The sky is held up by four dwarfs, the sun and moon chased by two wolves, the earth encircled by the World Serpent biting its own tail, and one of the three roots gnawed by the dragon Nidhöggr in Niflheim, the Lower World. (After Branston 1980, 73, Fig. 8.) - Odin hung himself in Yggdrasil "in order to learn the secret of the runes of wisdom"; he has described this vision quest in a song in Havamal, which is part of Verse Edda. He there refers to shamanic experiences, for instance "I'm aware that I hung/on the windy tree,/swung there nights all of nine; /[...]/ myself an offering to myself /[...]/ down to the depths I peered/to snatch up runes/with a roaring screech/ and fall in a dizzied faint! /[...]/ I grew and joyed in my growth;/from a word to a word/I was led to a word/from a deed to another deed" (Branston 1980, 115, after a translation by B. S. Phillpotts).

Most of the central figures have the shape of a tree with the roots at the bottom, a crown at the top, and the horizontal arm representing its branches. At the same time, they have (with a few exceptions) a rhombus at the intersection between the two arms, or the trunk and the branches. This rhombus may be regarded as the cross-section of the tree trunk (or the pole). The sun sign in its entirety could therefore be seen as the tree of the world viewed from above (or below!) and from the side, not a particularly unusual way of drawing. It seems quite natural, moreover, to compare the 
Tree of the World with the Nordic Yggdrasil and the cosmology connected with it, which has perhaps influenced Saami religion in other respects (see e.g. Reuterskiöld 1928), at least secondarily as Karsten has claimed (particularly with regard to the thunder god, Thor among the Nordic peoples, Horagalles i.e. old man Thor among the Saamis, Karsten 1952, $34 \mathrm{ff}$.). It is in any case remarkable to find the following links between the Saami drum pictures and the mythological figures of the Viking period (e.g. Branston 1980, 76f.; Brate, Noreen and Wisén in Nordisk familjebok 1904-22).

1. The tree as centre of the world and principle of organization: the square cross tree in c. 50 of the 72 (73) extant drums and the world tree Yggdrasil (or Lärad) of the Nordic peoples with branches which "spread far and wide over every land" (Branston 1980, 80); Roger Cook is one of many scholars who has combined ideas of the world tree and similar Axis Mundi concepts, for example in the form of a diagram of the mandala type (Cook 1974, 10, fig.) The tree or the pole as a symbol of the cosmic centre is often connected with the Pole star, around which the stars rotate once every twenty-four hours.

2. Three goddesses of destiny at the roots of the tree: Sarakka, Juksakka and Uksakka, the three helpers in childbirth, appear as border figures at the bottom of the lower right quadrant of the drumskin at the base of the rhomb-tree; they correspond to the three "Norns who dwell round the Well of Urd" according to Völuspa, who explains that they "every day take of the water of the well and sprinkle it over the Ash to prevent its limbs from withering or rotting"- - their names are Urd, Verdandi and Skuld.

3. Three holy figures of the underworld: 3 Ailekes, "Holy-day people" or "Holy ones", who stand by the lower part of the rhomb- cross tree, normally two on one side and one on the other; similarly, on the lower side of the tree, apparently at three different levels and in the underworld, there are also in Nordic mythology three beings-they are each rulers of a spring: Urd over the spring of Urdar in a world of gods under one of Yggdrasil's roots (Urd, the personification of fate, is at the same time the chief of the three Norns mentioned above), and then Mimer, the personification of Memory, over the spring bearing his name, under another of the tree's roots in the land of giants, and $\mathrm{Hel}$ at the Hvergelmer spring in the kingdom of the dead, Niflheim, under the third root, furthest down in the underworld with the dragon Nidhöggr gnawing at its root.

4. The close relation between the tree and birds: the thick lines on the right side of the drumskin may represent the Milky Way and the Saamisamong other names-have called this Lodderaddares, "the bird path"; the Nordic myths relate that the two original swans were given life at the spring of Urdar under Yggdrasil, and there is also an account of "an eagle roosting 
in the boughs of the Ash Tree, wise beyond all knowing, and between his eyes sits the hawk called Vedrfölnir"; both the Saami and the Nordic versions agree very well with the fact that the Eagle and Swan constellations are situated in the Milky Way near the centre of the Northern firmament-moreover perhaps the Nordic peoples were referring to the Milky Way when, speaking of Yggdrasil, they said "on the side it rots".

5. Snake creatures to the left of centre: a number of drumskins have zigzag figures on this side, either above or below the arm of the cross there, i.e. relatively near the rhomb- cross tree; the Nordic myth, as we have said, mentions the dragon Nidhöggr, "the Dread Biter", as the monster that gnaws Yggdrasil's third root deepest down in the underworld, in a nest of snakes and moreover that "A squirrel, by name Ratatoskr, darts up and down about the tree bearing spiteful tales between the eagle and the Nidhoggr"; star charts show a veritable nest of snake-like beings in the corresponding place: the constellation of the Dragon, the serpent with the Serpent-bearer, the Hydra and possibly al so the Unicorn.

6. Deer on trunk and branches: one or more reindeer or elks stand on the horizontal and/or vertical parts of the rhomb- cross tree, and sometimes next to it "in a free state"; Snorri Sturluson describes how "Four stags browse over the branches of the Ash and nibble at the bark"; the pictures of quadrupeds on the star chart may also be considered to lie behind this, particularly the animal pulling the Chariot (Auriga).

7. The tree, the goat and the deer, together with the god of death: on the right side of the drumskin on the "bird path" (the Milky Way) there stand in several cases a goat and one or more reindeer and just by them is a horseman (Rota, the god of death, who has been associated with Odin) who takes the souls to Jabme-aivo, the kingdom of death, over a bridge; this corresponds to the Nordic myth about a goat "Heidrun who stands on the hall roof/of Odin/ and browses Laeradi's (Yggdrasil's) branches whilst the deer Eiktyrner does the same"; on the right-hand side of the Pole star we find Capricorn, Aries and Pegasus, the latter identifiable with Odin and Rota (cf. Branston 1980, 80; Karsten 1952, 65; Sommarström 1985, 150).

8. Bridge of death; the above-mentioned bridge, over which both the Saami and the Nordic death gods carry the departed to the realm of the dead (on Odin's part the more "heavenly" Valhalla for those who have fallen in combat); the Nordic peoples had a name for this road or bridge, Bifröst, over which the gods rode every day to the spring of Urdar to hold council in heaven under the third root of the ash. But the thunder god Thor comes from another direction and has to wade over several rivers to get to the same council (e.g. Branston 1980, 85). If one tries to find constellations that are models for the death god and the bridge, Pegasus-as has already 
been suggested-lies close at hand, as does the line connecting the two Pisces, or the jet of water from Aquarius's pitcher, to exemplify ideas rather like that of the bridge (that Thor, like the constellation of Hercules, happens to be on the opposite side of the firmament supports this comparison to a certain extent).

The purpose of the above summary presentation of the similarities between the central signs on the drums and the myths around the world tree of the Nordic peoples is, as I have suggested, to indicate the possibility of some influence of certain nuances, perhaps in both directions. The subject is far too broad and intricate (cf. e.g. Eliade 1964, Ch. 8, especially $269 \mathrm{ff}$.) to allow for more than a brief sketch to show that it is certainly not yet exhausted, in spite of many attempts, more recently including those of Lundmark. Likewise it is probable that one can extract more from circumpolar comparisons, when the contents of the Saami drum pictures have been further scrutinized. ${ }^{1, *}$

There is much to suggest, however, that the cross tree on the Saami drums may be understood in the same way that Branston has interpreted the Nordic Yggdrasil, the guardian tree of all the world (Branston 1980, $81 \mathrm{ff}$.): "The most important clue here seems to be that connecting Yggdrasill with childbirth, with the creation of life, especially when we remember that Yggdrasill is an ash and the first man (who came from a tree) was called Ash. Yggdrasill then is a symbol of generation [...]". This power has the result that "the nine worlds", the Cosmos, will remain until the day when the tree falls and everything ends (Ragnarök)_among the Nordic peoples the reason for this was a "secret"; among the Saamis it was explained by Favna (the star god, Arcturus) with his bow (the Plough or Bear, presumably the Great Bear) shooting down the Pole star, according to the Saami Johan Turi in his book Muittalus samid birra, 1910 (reviewed in Sommarström 1967, 138). But the Tree is not only the Tree of Life but also the Tree of Knowledge, particularly knowledge of magic skills. Odin hung in Yggdrasil for nine days as a "sacrifice to himself" to learn the wisdom of the secret runes, until he finally fell into a trance; Yggdrasil was also called Odin's Horse and Mimer's tree, a relationship described in the myth by Odin sacrificing one of his eyes at Mimer's spring under the tree to attain

\footnotetext{
${ }^{1}$ Ernst Emsheimer and Krister Lindén have kept me continuously informed about studies in Russian on Siberian shaman drums and cosmology. I have been convinced that this comparative material could be analyzed pretty much along the same lines as I have now used for the Saami drums.

* The congress on "Shamanism in Eurasia" held 1981 in Budapest, with a report three years later, is of a special interest for the theme of my present article (finished before I could see that report, except Andreas Lommel's review in Anthropos 1985. Lommel 1985, 262 ff.). In his
} 
contribution "Cosmic Models and Siberian Shaman Drums" J. Jankovics interprets the paintings on the Uralic peoples' drums as "star maps" (an idea that he had presented already in 1979 in a symposium article) Jankovics 1984. This concept, and his observation that the more southern Altai peoples' drums even show zodiac constellations, are close parallels to my own interpretations of the figures on the Saami drums (first forwarded in 1980 at a symposium on "Pre-Christian Saami Religion" in Stockholm, later published in 1985, and then continued with a second part, first read in a tentative form at another symposium on Saami religion in Abo 1984, a final version of which resulted in the present article during 1985). A third major similarity is that the central cross-figure on southern drums is related to the quarternity principle based on the calendar (solstices and equinoxes) as well as on the cardinal points. The fact that some Siberian drums have paintings for temporary tasks on the upper side of the drumskin, and a representation of the universe painted on the underside, may account for clockwise or anti-clockwise arrangements of zodiac constellations-see our Figs. 8 and 12, and main text pp. 212, 235. Jankovics himself makes similar comparisons between Siberian and Saami drums regarding their interpretations (e.g. 151 for astrology, 152 for drums as "compasses").

The paintings (and handles) of the "magic" drums can be used as keys for opening the doors to the basic structure of the cosmologies of shamans and their societies. With or without pictures, the drums are potential spirit power containers as well as consciousness transformers and vehicles for the shamanic journeys into other "worlds". When painted (permanently and/or temporarily), their pictures mirror or symbolize different sides of "reality", for instance astronomical or geographical perspectives, together with corresponding spiritual qualities. Being real symbols, the pictures had to be orientated in space and time according to ordinary conventions, as well as to the general belief system of each society.

However, the practical use of the pictures was different between the Saamis and the other Uralic peoples. The former let some kind of object move around on the vibrating skin and point out appropriate figures for fortune-telling and other kinds of divination. The latter played "pitch and toss" with the dippershaped drumstick thrown on the ground (a method of which the Saamis have had some reminiscences down to our times), without involving the figures on their drums directly.

For other purposes-far-seeing, time/space orientation, curing, sacrificing, witch-craft-the drums (with or without permanent and/or temporary pictures) were used extensively in both groups, but seemingly with some additional differences between the Saamis and other Uralic peoples respectively. Firstly, among the Saamis many persons "though not all use this drum for divination" (Schefferus 1956, 177, citing Samuel Rheen), so it seems as if there were more shamans with them than further East. However, according to another contemporary statement, a lot of these drummers were more like laymen and not really shamanic: "They do not have a noticeable power spirit ["spådomsanda", of their own] and cannot orally communicate with such, like others do, but a [non-personal] spirit "speaks" exclusively through his drum and shows the place, where he can obtain game and such things" (Schefferus 1956, 177, this time citing Nicolaus Andrae Lundius). These persons were rather mediums sensitive to influences from powers who made them operate by means of drumsticks and pointers. Is it a pure coincidence, that their drumsticks, as well as some of their pointers, are Y-shaped like the typical dowsing rod (the earliest Nordic references to such being from the 16th century)? Ordinary shamans (noai'des) did possess power spirits who could for instance be sent away (with the help of drumming) to find out "what happens to their wives, children and reindeer" irrespective of the distance to their home cots (Shefferus 1956, 174, after Lundius) or what happens at the market place in advance before they themselves arrive there (Schefferus 1956, 173). This disposition plus the mastering of his own personal spirits, and of spirits unconsciously used at divination by laymen, made such a person acknowledged as a "mountain lord" or "mountain king", i.e. a noai' de (Schefferus 1956, 173, after Lundius). Some specially gifted persons had such an intimate relationship with their power spririts, that they were not exclusively depending on drums (even if they possessed such), at least not for clairvoyance; "these are the most successful ones" (Schefferus 1956, 153, 173, referring to Johannes Jonae Tornaeus). 
further magic knowledge. This has been linked with Odin's role as god of the Heavens, the Sun god; similar connections of tree/trance, tree/sun are found on the Saami magic drums with the rhomb- cross in the middle. The possible link is reinforced by the fact that the bark of the tree is used for the red colour for painting the drum figures, and that the wood for the drum must be taken from a tree which has grown "with the sun", and that the same anti-clockwise movement was required at least for certain hunting predictions when the pointer was started from the middle of the rhombcross tree (according to Rheen and Niurenius, quoted in Schefferus 1956, 174). Particularly Niurenius states clearly that the arms of the rhomb- cross show the four points of the compass "as a guide to the drummer and the hunter, where he should that day wend his way" and moreover what game he would manage to catch, when certain of the animal figures on the skin of the drum were indicated by the pointer.

The skin of the drum has, in other words, been geographically orientated with the help of the painted central sign, the rhomb- cross tree. But how? And in what way, then, is a possible projection of the firmament compatible with a map of orientation for the earth, where naturally a bear is a bear and not a constellation, and the remaining reality nearest human beings is seen quite clearly.

When the present study was begun (in 1980) and certain fairly vague resemblances between drum figures and a number of constellations appeared evident, it was necessary to test these assumptions by searching for a method with which to organize the mass of figures. I quite simply extended the arms of the rhomb- cross to the edge, upon which the whole picture surface became divided into four equally large fields. The quadrant system thus produced became the frame of reference to which the individual figures could be related, since one could now easily see in which quadrant (or at least pair of quadrants) they were mostly located. The positional tendencies could thus be observed and measured in relatively fixed numbers and when the frequencies were high there were grounds for comparing the relevant figure more closely with the corresponding constellation on a star chart. This was also done for some of the figures which occur "freely" on the drum skin between the edge and the central figure (Sommarström 1985). The corresponding analysis, although with different results, has now been completed for the complex of details on the central rhomb- cross sign, as follows below; after this the same method of study is applied to the figures around the edge before a total analysis can be made in an attempt to answer the questions outlined above.

The 41 drums with a central cross figure and the 9 examples with the $\mathrm{T}$ shaped division of the picture area (the latter with a less centrally placed 


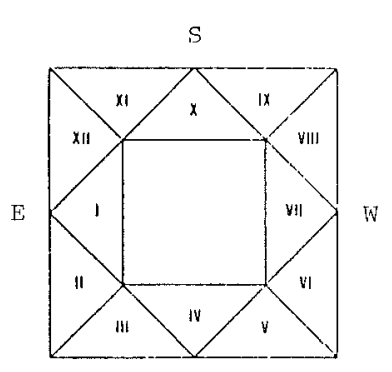

$\mathrm{N}$

a

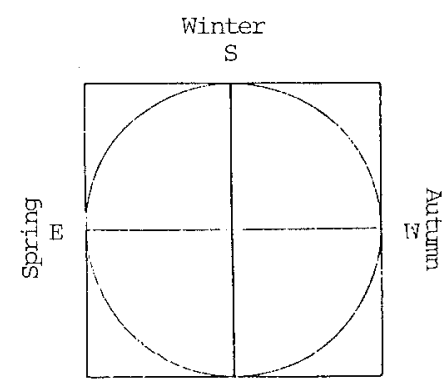

$\mathrm{N}$

Summer

b

Fig. 7. Geometrical structures of macro-micro-cosmic relationships. a The traditional square "envelope" type of horoscope, consisting of a table with 12 "houses" or divisions of time for various human qualities and circumstances to be combined with the actual positions for sun, moon and the planets. $b$ The quaternity principle, a symbol of wholeness as well as a way of showing mundane time-and-space orientation. The yearly course of the sun is represented by the crossed lines of the spring and autumn equinoxes and summer and winter solstices respectively. The high points of the seasons and the four cardinal points roughly coincide in this model which is also part of the astrological technics. Note the order of solstices/cardinal points, which is an astrological abstraction (as if seen "from above"), and reversed in comparison with "natural" astronomical views (as for instance in Figs. 12 and 13-18). Spring equinox, East, and the zodiac sign of Ram (Aries), all joined to the left, with the corresponding star constellation nearby. (After Schwabe 1951, Abb. 53 and 2.)

cross-like figure) all largely display the following more or less common features.

The middle part of the cross is shaped like a rhombus except in 8 cases (nos 2 and 50 with only a crosscut, and 6, 15, 16, 36, 51, 52 with a circle at the point of intersection); the figure moreover is a more or less tree-like cross with a root and crown (complete exceptions are 3, 12, 19, 29, 36, 49), and has elks or reindeer, people and plants in the rhombus and/or on the arms of the cross in varying numbers (with the possible exception of 36 ).

A reindeer occurs in 18 of the rhombi, cross = a human? figure appears in two rhombi $(45,5)$ and in two circles $(6,51)$, a more anthropomorphically shaped person in the rhombus in no. 17, a dot in the rhombus (9) and in the circle (52), together with a unique rectangle with "horns" and a central dot inscribed in the rhombus of no. 19. It is more common that a reindeer or elk appear on one or more arms of the cross: single ones are found in 18 
examples, 2 in 8 examples, 3 in 12, 4 on 2 drums, but they are missing in 7 or 8 examples $(9,36,45,5,17,47,48$, possibly $49,50,51,52)$.

The human-like figures can be divided into two groups: those which stand on the three upper arms and those which have been designed in greater detail (in many cases with accessories), and those generally executed in more stereotype fashion on the lower arm, normally regarded and designated as a group. A single figure may be noted on 3 drums, 2 on c. 13 examples, 3 on about 18, 4 on roughly 7,5 on 3,7 on 2 , and $16(!)$ on one example (no. 29) where all however consist of simple small crosses (except for one cross in the central rhombus and a three cross group on the lower arm). The group of several figures on the arm of the cr. pointing downwards is in several sources called Ailesolmak, "the Holy or Holy-day men", or the saints; they were regarded as protecting the weekends (Friday, Saturday and Sunday respectively). The figures are three in number in at least 26-i.e. about half of the cases, and this corresponds to standard source information that they should be three in number. In 7 cases there are only two figures, several cases are unclear and several lack this group of people on the lower $\operatorname{arm}(21,32,41,45,46,154,5,17,47,49,51,52)$.

The plants, finally, are not so prominent as the other figures on the cross. They play the more subsidiary role of twig or staff in the hand of a human figure on the left-hand arm of the cross, or of projecting branch or top branch on the upper arm (where it moreover alternates with the rather similarly shaped elk's antlers or even a whole elk). In some examples $(8,11$, 12) the crown of the tree has been topped by a building. No. 14 has, in the corresponding position, a figure which is difficult to interpret (see Manker 1950,261 , no. 14:4) but is perhaps influenced by the elk.

\section{The border figures}

The number of figures beginning at the border line (which is heavily painted and often double) varies greatly, among other reasons because many of the figures have become partly or completely indistinct or perhaps obliterated (in his lengthy analysis of the drum pictures Manker has put question marks at the corresponding places on the drum skin). Some drums have anything up to 30 border figures, others have only one or a couple (remaining?) while most of them lie between these two extremes. Nevertheless, there are some drums with more common frequencies (29 of 50 drums with the central figure), and most of these are gathered in an area between 14 and 19: 4 examples have 14 border figures, 5 examples have 15 , the same number 16 and also 5 examples have 19 border figures. No less than 7 drums have 18 
figures, and 8 have 17 on the border. Other numbers of interest are 22 and 26 (on three drums each).

The general impression of the border figures is that they are fairly stereotype compared with the free figures between the border and the central figure. This impression is formed by the fact that when one compares the 50 examples in question, one soon notices a certain regularity in the positioning of the figure types; the actual depiction of these types is completed in a highly individual way, and it is therefore difficult to distinguish between, for example, houses, tents, turf-huts and altars and even churches. The latter are distinguished by one or more crosses but these crosses are also found with other figures, designated as graves or sacrificial altars (Manker 1950, 303, interpretation of 28:33), Saami deities (Manker 1950,303 , interpretation of $28: 29$ ) etc., a range that depends much on the fact that crosses also represent people.

One border figure which is nearly always easily recognizable, and which as a rule is restricted to the lower left-hand (3rd) quadrant, is the njalla, the meat store on a pole with climbing log leaning against the store. The "njalla" was and is a type of storehouse above all for meat, and it is placed on a pole so that the wolverine and other animals will not be able to get at the contents. Above all, the njalla at the spring and autumn home was filled with meat from the early reindeer slaughter before the rutting period in the latter part of September, so that there would be a reserve supply on returning the following spring-thus it was not necessary to carry meat from the winter's main slaughterings. The njalla is thus principally connected with the early autumn slaughter in September (Manker 1947, 157), and if this time link lies behind the positioning of the njalla figure, then it should be in the 3rd quadrant assuming that the curves on the right hand side of the majority of the drums correspond to the Milky Way, Johan Turi's "Bird Path" or Year mark, which would coincide with the monthly division on an ordinary star chart of the astrolabe type (e.g. Björn Hedvall's Astrokarta). This is also the case, as has already been stated, but it can be shown more clearly as follows: of at least 33 observable njalla figures on the 50 drums in question not less than 29 of them are in the 3rd quadrant (1, $2,3,6,7,8,10,11,15,16,19,22,23,24,25,26,27,29,32,33,35,37,38$, $39,40,154,5,17,47)$. Three of these $(11,16,32)$ actually have double figures, i.e. two njallas. Nr. 38 shows a person going up the steps on his way to the store itself. Two more njallas $(13,31)$ are on the border between the 3rd and 4th (upper) left quadrants, and only two deviate from the main position in the 3rd quadrant: in 34 the njalla is in the 4th and in 51 in the 2 nd quadrant.

Njalla was also the name of one of the Saamis' own constellations, which was also called "Aaron's staff'. It is mentioned in later times together with 
the Milky Way (Dalvegäinos), the Plough/Bear (Sarva) and the Pleiades (Lovosj) as the most important constellations (Pettersson 1979, 84). At least the njalla among the border figures may be astral, provided that it really represents the njalla constellation, as well as the Milky Way, which is both a border figure and a figure in the central zone.

Two other constellations may also be distinguished as being particularly emphasized, in that they are relatively large and sometimes complicated, and by their positions at either end of a straight line through the middle of the rhomb-cross; this line corresponds to the line across the middle of the oval drum. When the drum is held horizontally, an often magnificent sacrificial platform with i.a. an elk and a bear appears at the "front" end. With the "Milky Way" on the right, this platform (there are several others) has a position corresponding to the constellation of Ara, "the altar", which is depicted as an altar for burnt sacrifices on old star charts (e.g. Apianus 1540, see Fig. 10). Its antipole and the opposite end of the central line is a figure, normally resembling a reindeer pen, a round enclosure with one or more reindeer inside. I have previously pointed out that it should in this case be a milking pen, where the reindeer cows were gathered at least once a day in former times, when the reindeer were either quite tame or were wild reindeer hunted or captured in pits amongst other places (Sommarström 1985, 152f.; cf. Manker 1950, 310). This figure on the drums has a position corresponding to that of Orion on the opposite half of the star chart; Orion is represented as hunter or warrior with a club and sword and three stars as a belt. Orion has been known from earliest times as a marker of the seasons, e.g. "[...] when Orion rose at dawn it was taken as a sign of approaching summer; in the evening, as a sign of winter and storms [...]", (Orion 1982, 583), together with the neighbouring Sirius. The myth of Orion played the role of a link between heaven and the underworld (cf. "the sign of the underworld', Manker 1950, 43:583), between gods and mortals and between mortals themselves, in multifarious rites de passage. If the constellation is positioned behind the drum picture, which resembles an enclosure for milking the reindeer cows during the short summer period, then it is well-chosen as a mark for the summer solstice.

I will not consider any of the other figures in greater detail. It is, above all, important to see the border figures as a whole, together with the "freer" figures further in on the drumskin and the central complex of figures. It will be apparent that certain functions are common to the pictures on the edge and the "free" pictures, and that thus there may sometimes be overlaps (a typical example is "the Milky Way"). At the same time it seems that all the border figures nonetheless have a special function as a basis for computing time. 


\section{The orientation of the magic drum}

The starting point of the study was that the thick lines with figures, which in the drums with a rhomb- cross sign in the centre occur on the right-hand side in practically every case (according to Manker 1950), may correspond to our galaxy, the "Milky Way". If a number of the other drum figures are also connected with the star constellations, as we have tried to suggest above, it should be possible to use a magic drum of this kind purely practically as at least an approximate star chart or astrolabe (a star chart with an ecliptic with which at any given point of time one can read the position of the stars and planets in relation to the horizon).

Why should the shaman need to orientate his drum at all? The answer is that he had to co-ordinate his instrument as well as himself with "ordinary" reality before he could set out on journeys to the other "non-ordinary" reality (in Castaneda's terminology; see Harner 1983, who for his part prefers the terms Ordinary state of consciousness and Shamanistic state of consciousness; a survey of this is also given in Hultkrantz 1985, 511). Regardless of whether the shaman intends to make his way to the heavenly, earthly or subterranean sphere, he must begin from a place he himself has chosen as "anchored in reality"; it may vary but must be one which he "really" knows: for a heavenly journey it may for example be the smoke hole of his tent, or a tree-top, for an underground journey it may be a tree root or a hole in the ground, and for a spiritual excursion into "the real reality" on earth he must chose a starting point which is for him "suitably" high. (Almost anyone can experience this who has the opportunity to take part in so-called shamanistic exercises or genuine shaman journeys, according to Harner 1983, inter alia.) ${ }^{2}$

Before we proceed from the above assumptions to test the possible applicability of the Saami magic drums as astrolabes, some basic elements of astronomy and astrology should perhaps be introduced. Here I largely follow an account in Mann's standard work. "The conventional horoscope represents the elliptic and the 4 angles are called Ascendant, Midheaven/Medium Coeli/, Descendant, and Lower Midheaven/Immum Coeli/ respectively." "The horoscope is always oriented with the ascendant (east) to the left and the descendant (west) to the right [...] South is at the top of the page, while north is at the bottom [...] The four cardinal points in the plane

\footnotetext{
${ }^{2}$ Michael Harner once showed his copy of a Saami drum to a man, who belongs to one of the large North Saami kins. He turned the drum slowly, tapping different parts of the skin while listening attentively to the sounds. Then he said: "This is East". (Personal communication, June 1986.) Is this a matter of personal speculation by this modern Saami, or does this event reflect some sort of traditional knowledge?
} 


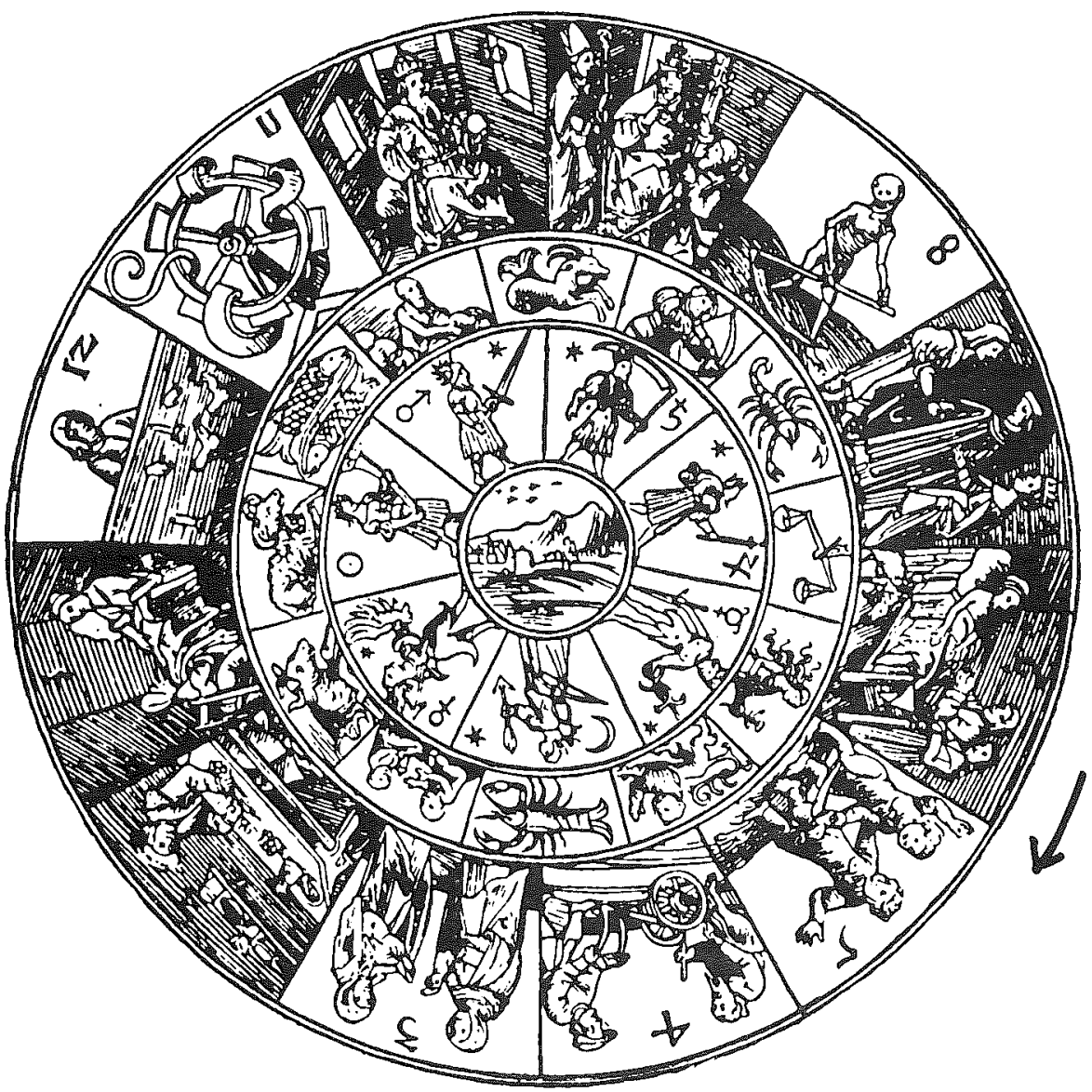

Fig. 8. Human activities "typical" for the 12 months and "houses" in combination with the 12 signs of the zodiac, and the 7 planets who govern the psyche of the individual. Note the clockwise direction of rotation, which is the rule for Western astrologers (cf. e.g. figs. 9 and 10). The Saami shamans' zodiac-like star constellations are set in a more "natural" counter-clockwise order as seen from the earth, according to our model chart (fig. 12) and its application on drums with central cross-design (figs. 13-18). (European woodcut, 1515; after Kenton 1974, Fig. 22.)

of the ecliptic are north, south, east and west points equivalent to $0^{\circ}$ of the astrological signs Cancer, Capricorn, Aries (these last two interchanged by me for better accuracy) and Libra. There are correspondences between these two systems. The four cardinal points correspond to the four seasons and important hours of the daily cycle. The ascendant is equal to the vernal equinox and sunrise; the MC to the summer solstice and noon; the descend- 


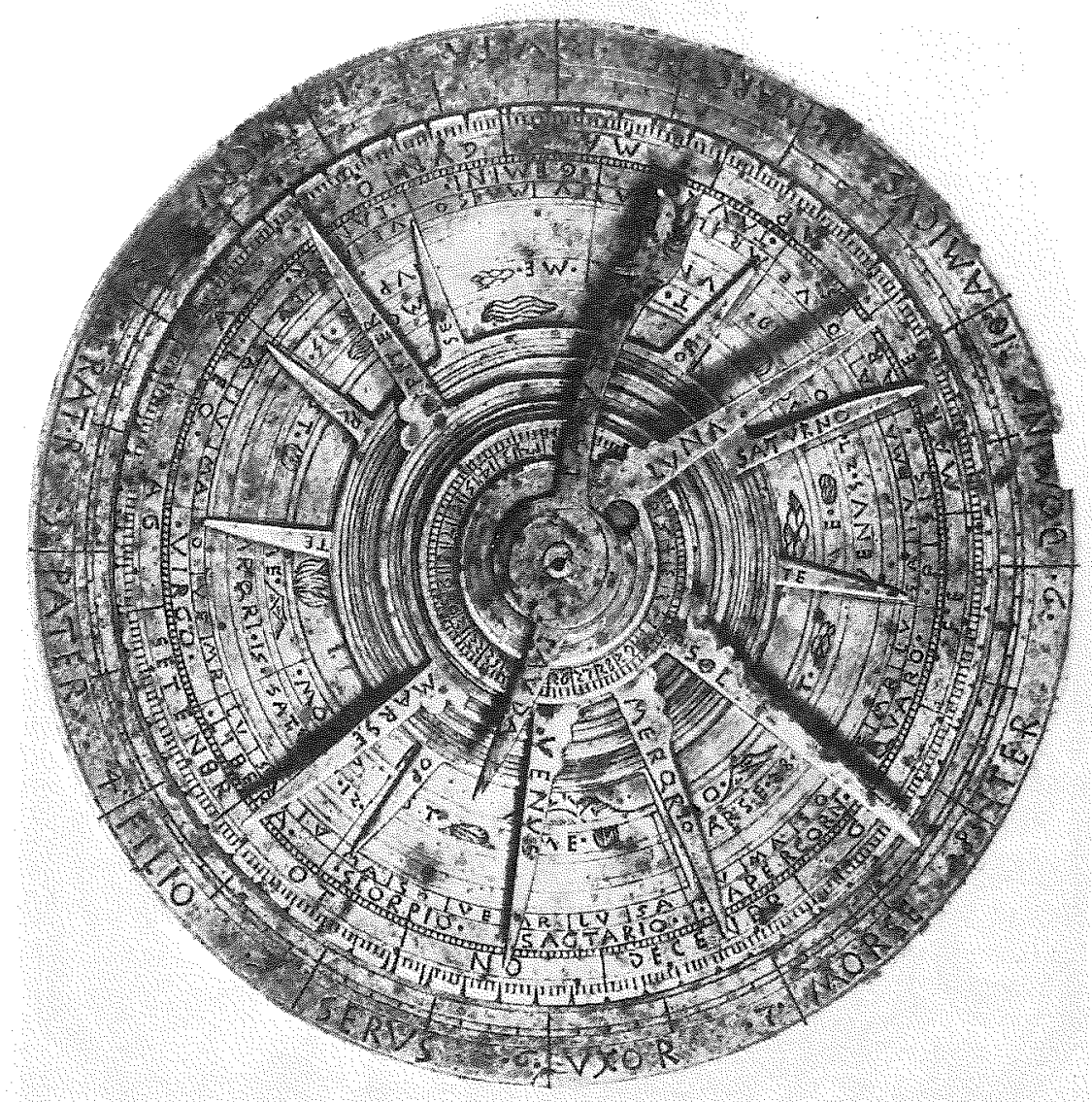

Fig. 9. Astrolabe of brass for "instant"' horoscopes (European, c. 1450-1500). With this special type of astrolabe the medical doctors could quickly calculate the proper time for treatments. Each movable arm represents a planet (including the "dragon's head and tail") and can be turned to point at the relevant zodiac position. The outermost circle contains the 12 "houses". (Kenton 1974, Fig. 52.)

ant to the autumnal equinox and sunset; and the IC to the winter solstice and midnight" (Mann 1979, 60 f.).

A. T. Mann makes the following comment on the four part relationships in time and space: "The combined division of the zodiac by the ASC-DES and $\mathrm{MC}-\mathrm{IC}$ axes produces a division by four, a quaternity. The quaternity is extremely important in psychology, religion, astrology and mathematics." And he cites Carl Jung's views in Psychology and Religion (p. 167): "The quaternity is an archetype of almost universal occurrence" and that it 


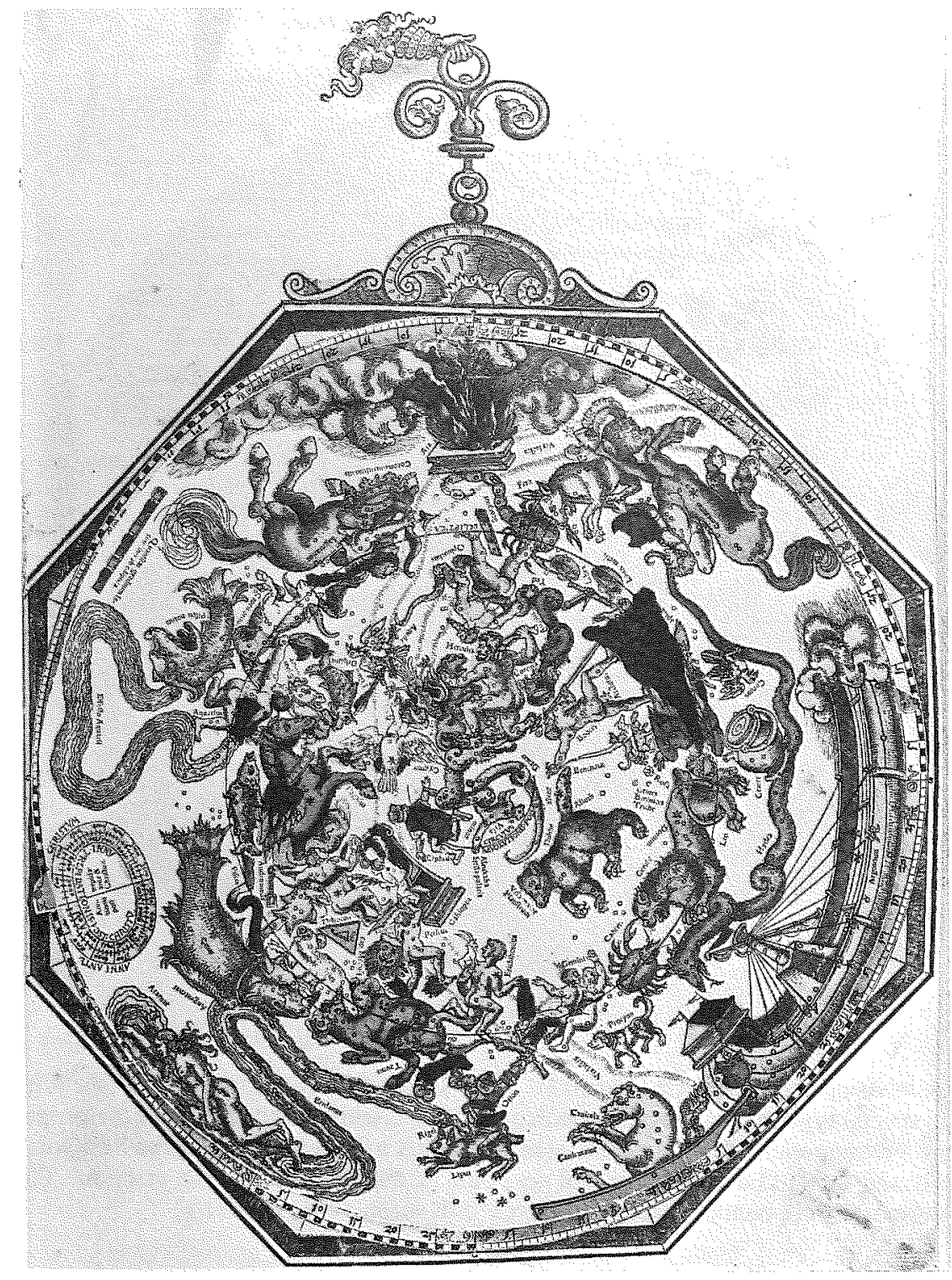

Fig. 10. Astrolabe of cardboard for astronomical use, one of a series bound together in the book "Astronomicum Caesarum", published 1540 by one of the foremost preheliocentric astonomers Peter Apianus. Another famous astronomer of the same century, Tycho Brahe, had a copy of the book and both probably used these instruments for their astrological tasks as well. The main disc contains the zodiac constellations and can be turned around with the protruding pointer (here to the left) to positions in relation to the outer circle (on the octagonal board below), which is divided in the 12 zodiac signs and the $360^{\circ}$-scale. The sacrificial Altar (Ara) is a constellation of the Southern hemisphere near the constellation of Scorpio; the quite disproportionate size of the Altar here might have some religious significance (cf. the similarly large sacrificial altar at a corresponding place on the Saami drumheads with central design, at the time of the winter solstice). 
"constituted an essential psychic mechanism in the search for wholeness". Mann also points out as examples of this that "Most spatial orientation systems and models of the universe use four points in their structure. The cardinal points of the compass, [...] the faces of the square representing Earth, [...] and the religious systems of many pre-Christian cultures are all examples of the orienting faculty of the quaternity" (Mann 1979, the section on "Quaternities" $71 \mathrm{f}$.).

This division, as mentioned previously, is one of the bases of the astrological systems, which have used both round and rectangular graphic aids for their calculations. The rectangular "envelope horoscope" was the dominant one from Roman times up to the beginning of the 20th century (see e.g. Schwabe 1951, 53, 54); it is this form which I believe has contributed to the occurrence of the rhomb- cross sign on the Saami magic drums. And the most obvious four-fold division in the context of the calendar and annual cycle which the Saamis could have been in close contact with must have been the four solstices-equinoxes.

The second step in our continuous study of whether the drum pictures were organized according to a cosmological system meant that a test had to be performed to see whether the fourfold division of the picture areas produced by the rhomb-cross also had an equivalent in the relation to the seasons and solstices-equinoxes. I avoided the more complicated horoscopes and used Björn Hedvall's admirably simple "Astrochart" of the northern firmament, produced for school use, and which is divided precisely by lines joining solstice-equinox points on a circular line round the firmament, connected with the twelve months and the 24 hours of the day (Fig. 12). I decided to turn the chart so that the Milky Way came on the right-hand side, as on the Saami drums, in positions which corresponded to solstices and equinoxes. I then followed the instructions for the chart, which run as follows:

"1. Stand facing south. 2. Turn the chart so that the name of the present month is right at the bottom. Then the chart is orientated around 6 p.m. 3 . When using it later than $6 \mathrm{p} . \mathrm{m}$. turn the chart anti-clockwise as many hours as have passed from 6 p.m. to the time of use. The chart is then orientated for that occasion. 4. Hold the chart overhead and read it from beneath." I then obtained the following 4 alternative explanations for the fact that the Saami drum pictures have the Milky Way on the right-hand side: they were positioned at the spring equinox (nowadays on 21/3) at 6 p.m., when the sun sets and night and day are of equal length, or at the autumn equinox (now on 23/9) at 6 a.m. when the sun rises under the same conditions; the problem, however, is to find what natural phenomena in the heavens could lead the Lapps to an orientation of this kind (which in southern cultures 


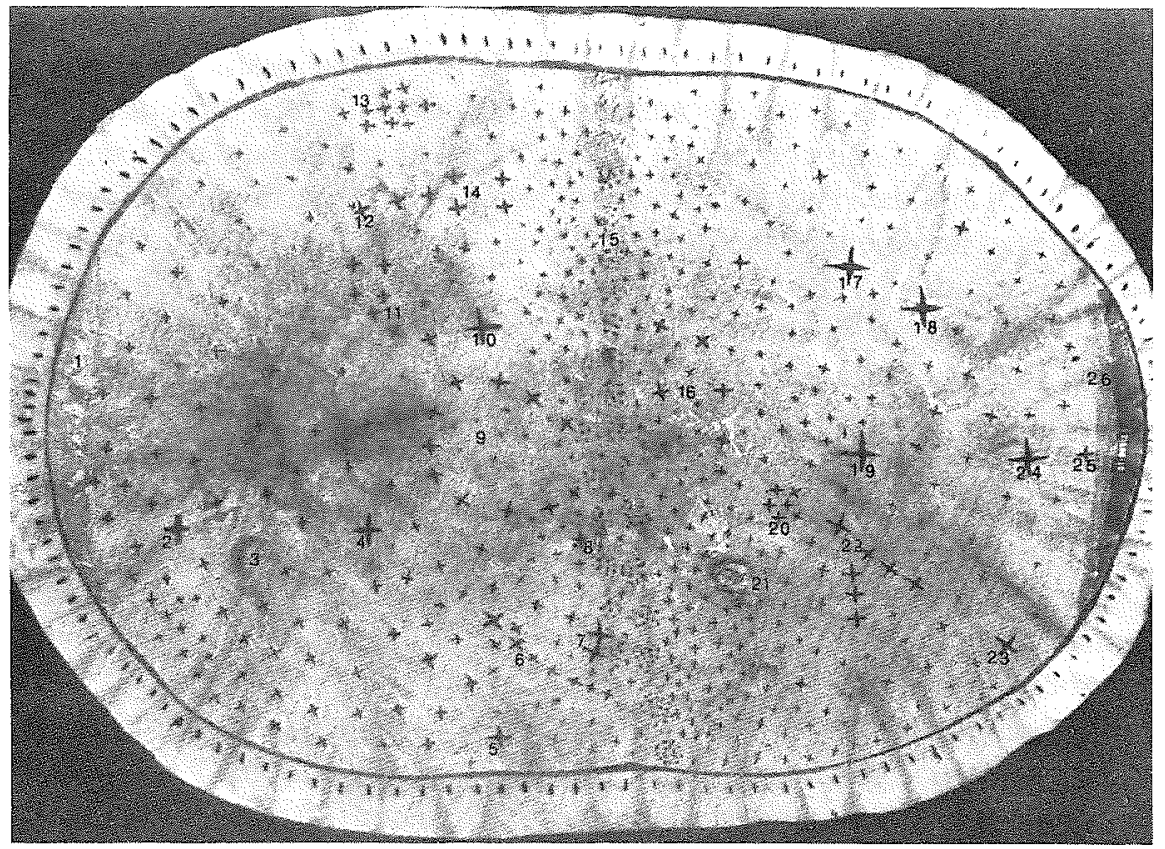

Fig. 11. Star map painted on skin, one of the items in a sacred bundle used in ceremonies by Skidi Pawnee Plains Indians, long time before the Field Museum acquired it in 1906. A round brass object representing the earth went with this chart of the heavens. Several star constellations have been identified, e.g. the Milky Way (across the middle) which is called the Path of the Departed Spirits, who walk to the Southern Star. The Pawnee "were obsessed with the sky-particularly those of the Skidi band who were, in a sense, the astronomers of the tribe" (Von Del Chamberlain 1982, 11, $185 \mathrm{ff}$, Fig. 47), - Not all Saamis, who used magic drums for divination, were acknowledged as true shamans, i.e. possessing own spirits, good medical skill, or more than average knowledge of astronomy. The poor execution of the designs on many drums rather suggests that the owners were ordinary laymen, the masters of households, with only elementary shamanic techniques.

with their refined methods of calculation and other conditions have led to the situation where the spring equinox has become the time for the basic orientation of the astrolabe). The next likely alternative is to position the chart in accordance with the summer solstice (now on 21/6) at 12 midnight or the winter solstice at 12 noon, positionings which also show the Milky Way on the right-hand side of the heavenly sphere. In choosing between the two, one must for reasons of practical orientation take the following factors 


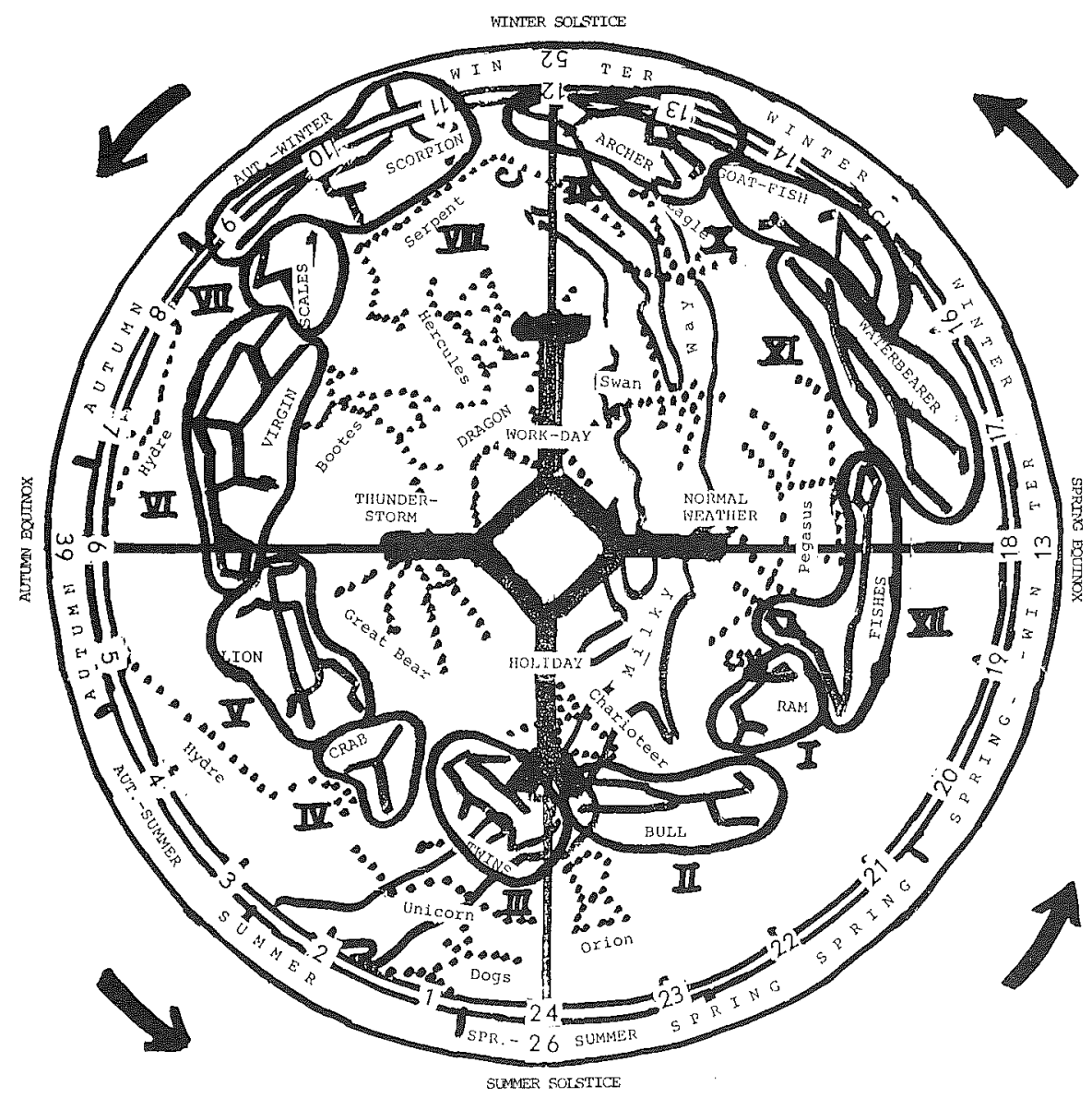

Fig. 12. MODEL CHART for interpretation of Saami drums when used as "astrolabes". The 12 star constellations of the zodiac (continuous lines) run counterclockwise, which is the natural impression when the sky turns around (making a complete circle during 24 hours). At one common kind of divination "soft" drumming moved a pointer (which could have several forms, e.g. rings or a toad-figure of brass) around the figures painted on the skin. The central design (here conventionalized and with very tentative sub-features) is a cross-tree with intersecting rhombus representing the sun according to the Saamis, which suggests the sun's yearly course with resulting orientation in time and space: hours, or rather 3-hour-intervals as by the ancient Saamis; weeks in 13 four-week-periods, and seasons, in a second circle with clockwise direction; the 4 cardinal points (with South at the top and East at the Autumn equinox) are opposite to those of the sky (after which the constellations have been orientated). The Milky Way (continuous lines) has been the most decisive feature for the construction of this model. Solstices and equinoxes are according to the modern calendar, for convenience's sake, but were earlier at the time of the drums. The Winter Solstice, for instance, was on December 11 at the beginning of the 18th century, and most of the preserved Saami calendars started the year between this date and December 24, apparently a mixed system (Granlund \& Granlund 1973, 16-29; Jansson 1974, 125). 
into account: at midsummer in the northerly Saami districts the sun is up all night; in the farthest north it never sets but makes a sort of "curtsey" at midnight, which could be a suitable choice of time to observe how the constellations are then positioned at the different points of the compass. The problem with this alternative, however, is that the sky is so bright that it is difficult to observe the stars and classify them more exactly. The latter alternative - the winter solstice-seems to me to be the best; at about 12 noon during this part of December the sun is up for only about an hour and can therefore be easily observed in relation to the points of the compass and, what is important in the present context, in relation to constellations which can be observed in the daytime immediately before and immediately after the sun appears. One can say that the solar clock and the stellar clock coincide. In addition to this, the constellation of Orion stands practically in the south, as does the neighbouring bright star Sirius; both are among the most common direction markers in different cultures for the purpose of calendars, and appear in the south at the summer and winter solstices and the spring and autumn equinoxes-although they ought to shine most brightly in the winter.

There are two more arguments for the assumption that the drums were orientated to depict the night sky at the winter solstice. I shall now quote from an 18th century source which is probably not widely known: Per Alstadius's account of conditions among the Saamis during the first half of the 18 th century. Alstadius had been a priest for 30 years in the Lappmarks, particularly in Kvikkjokk; his expertise in Saami culture has admittedly been called into question on the grounds that he never really learned the Saami language (Jansson 1974,125 ), but he should nevertheless be regarded as able to stand for his opinions which he published in the journal Lärda Tidningar in 1750 under the title "Astrophysica Lapponica". Alstadius claims that this is an "Architectonic notion which Lapplanders possessed in bygone times of the natural power of the heavenly bodies and their influence down here on the earth"'and which Alstadius himself had learned from "the reports of old men and from personal experience"'. He largely restricts himself to the way the Saamis counted time, and begins with the periods of the day which were counted in three hour spells: beginning from midnight to $3 \mathrm{a} . \mathrm{m}$. and then from 3 to $6 \mathrm{a} . \mathrm{m}$. etc. The Saamis originally had no system for counting months, but followed a system with $4 \times 13$ weeks (see Granlund \& Granlund 1973, 22, 29), which was the basis of the calendar sticks which constituted the Saamis' almanacks (in bone and wood) until the 18 th century. But Alstadius points out that they nonetheless celebrated the new moon, which corresponds in practice to counting months; in the beginning of the 18 th century the Saamis therefore had, in 
addition to the old system, the time system borrowed from the Nordic peoples. "The years were begun from the winter solstice and also divided for the number of months into four seasons, which were each marked and celebrated by three days of sacrifice, smoking, prophesying and every kind of joyful manifestation, in accordance with what the season and the circumstances required and the occasion permitted. The first season began in Momento Solstitii Brumalis and lasted until Momentum Aequinoctii vernalis, during which time Elementum Aëris was held prominent as Maxime regnans and the issue brought forth at that time inclined to Temperamentum Melancholicum. The second season was calculated from Momento Aequinoctii vernalis and lasted until Momentum solstitii Aestivalis, during this time Elementun Terra was maxime regnas and the issue brought forth inclined towards Temperamentum Sangvinicum as maxime regnans." It goes on in the same style and states that the third quarter has fire as its element and the choleric humour as its temperament, whilst the fourth quarter had water as its element and phlegm as its temperament. The equivalent coupling of the calendar with nature and human beings is widespread and it seems that the system just described could have been taken over directly from the Nordic neighbours-although this does not prevent the Saamis from having had a similar psycho-cosmological system previously. But the question is whether the system described with the seasons, the four elements, and man's basic mental characteristics, also applied to the drums, was present in some way at least in the consciousness of the noai'des when they practised divination with the help of the drum.

The details provided above should in any event offer support for the idea that the drums were orientated after the winter solstice: it would be natural to begin in time from the Saami new year, i.e. the winter solstice. And in this case the time for the position of the stars follows, as it were, automatically: it becomes 12 noon.

The star chart or astrolabe, which is reproduced here after the 16th century astronomer and astrologer Apianus (Fig. 10), has been orientated after the spring equinox (now 21/3), where another greater chronology has also been provided: "Christi Geburt" in the year 0 (together with scales for 7000 years backwords and forwards in time respectively!). But Christ's birth is celebrated at Christmas every year, and it is conceivable that the Saamis combined the old calculation of the new year with Christmas.

The above discussion has brought us to the third stage of the study, where the border figures have been interpreted as possible markers for the divisions of the day and the year; in short, the chronology which converts the Saami drum into an instrument comparable to an astrolabe. Space does not permit the presentation of all the results in the present context, but the 
reader is referred to the results given as a tentative model (Fig. 12); this may be used as a "pointer" when looking for analogies on each individual drum, partly all the drum picture surfaces with such figures encircled as I, for my own part, thought I could identify preliminarily partly with the twelve constellations of the Zodiac, partly with some other constellations (Figs. 13-18).

Orientation in accordance with the four cardinal points is part and parcel of the system based on the four points of intersection of the ecliptic, as with the seasons and other time markers. Thus if one of the factors in the system is unknown, say for example the point of the compass when one is surprised by fog and unable to see the sun, or at night and cannot orientate oneself by the stars, it should be possible to determine the direction exactly, as one naturally knows which month one is in and has a fairly accurate idea of the time of day at which one got into difficulties. One simply takes the drum, turns it until one gets the relevant month (or the corresponding group of weeks) according to the border figures against one's body, then turns it once more so that the drum is as many hours (or thirds of three hour periods) clockwise or anti-clockwise as one is after or before the time of the day at which the drum was originally orientated, i.e. 12 noon (if my calculations above are correct). Suppose that it is about 12 midnight on one of the nights round the summer solstice (nowadays on 21/6). The front part of the drum should then point towards the south! This whole hypothesis could explain the complaint of the old noai'des that they were deprived of their equivalent to the "compass" of the Nordic peoples, the magic drum.

\section{The ethno- and archaeoastronomical importance of the magic drum}

It has been necessary to consider the technical questions in such detail, that there is no space in this context for a fourth stage in the study, to include the Saami magic drums in a larger comparative study of phenomenological character. The preparatory work has been completed and is considered in

Figs. 13-17. Tentative interpretations of possible zodiac-like arrangement of some of the figures on Saami drums with central cross motif. (Other possible star constellations have been proposed in Sommarström 1985.) The drums are numbered according to Ernst Manker's system in his Die lappische Zaubertrommel, where he gives his explanations of all individual figures which he had been able to perceive, giving question-marks to the many obscure traces. The zodiac constellations (I-XII) of real star maps are shown in the MODEL CHART, fig. 12. 

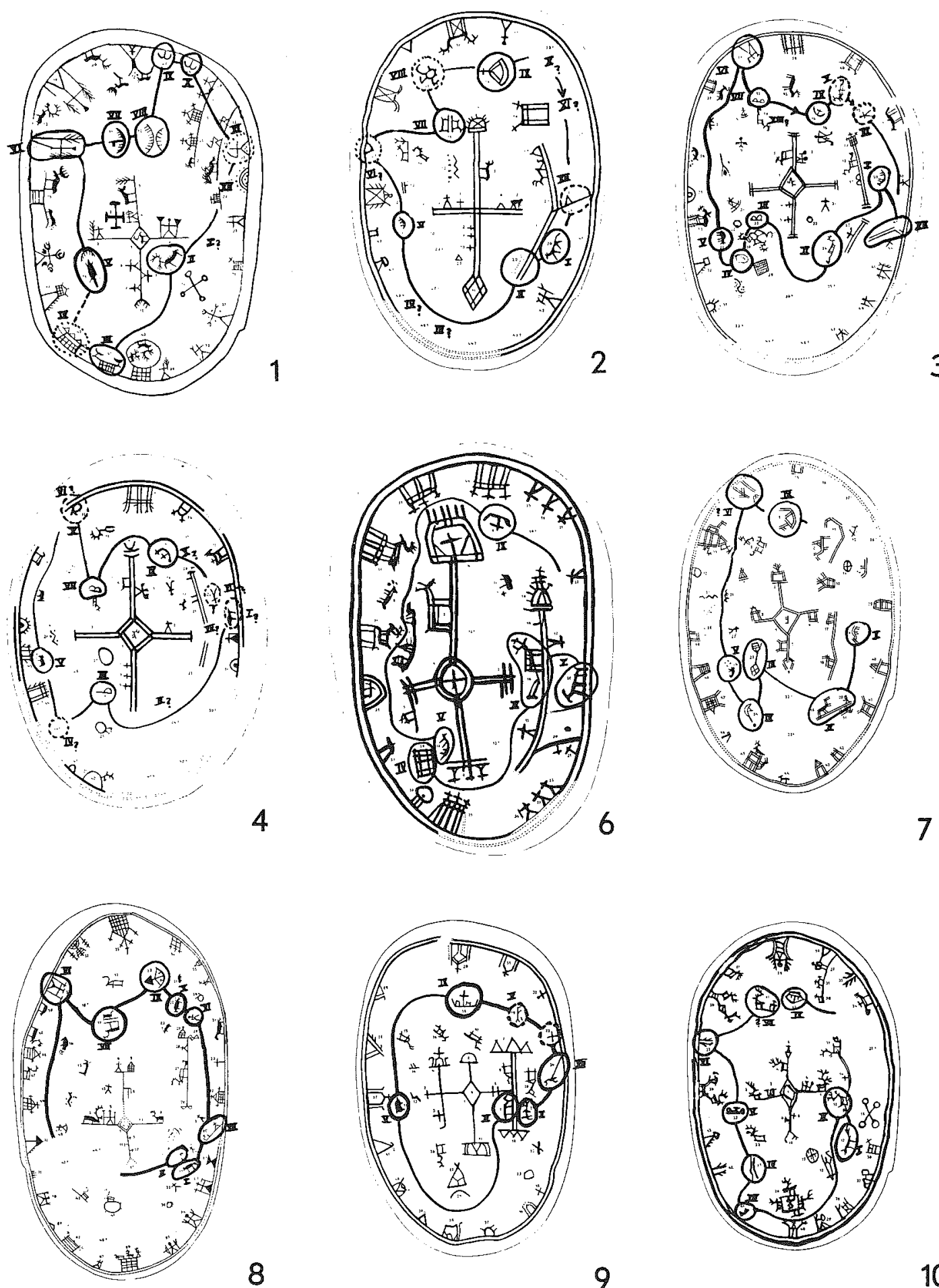

9

Fig. 13

16-869071 Saami Religion 

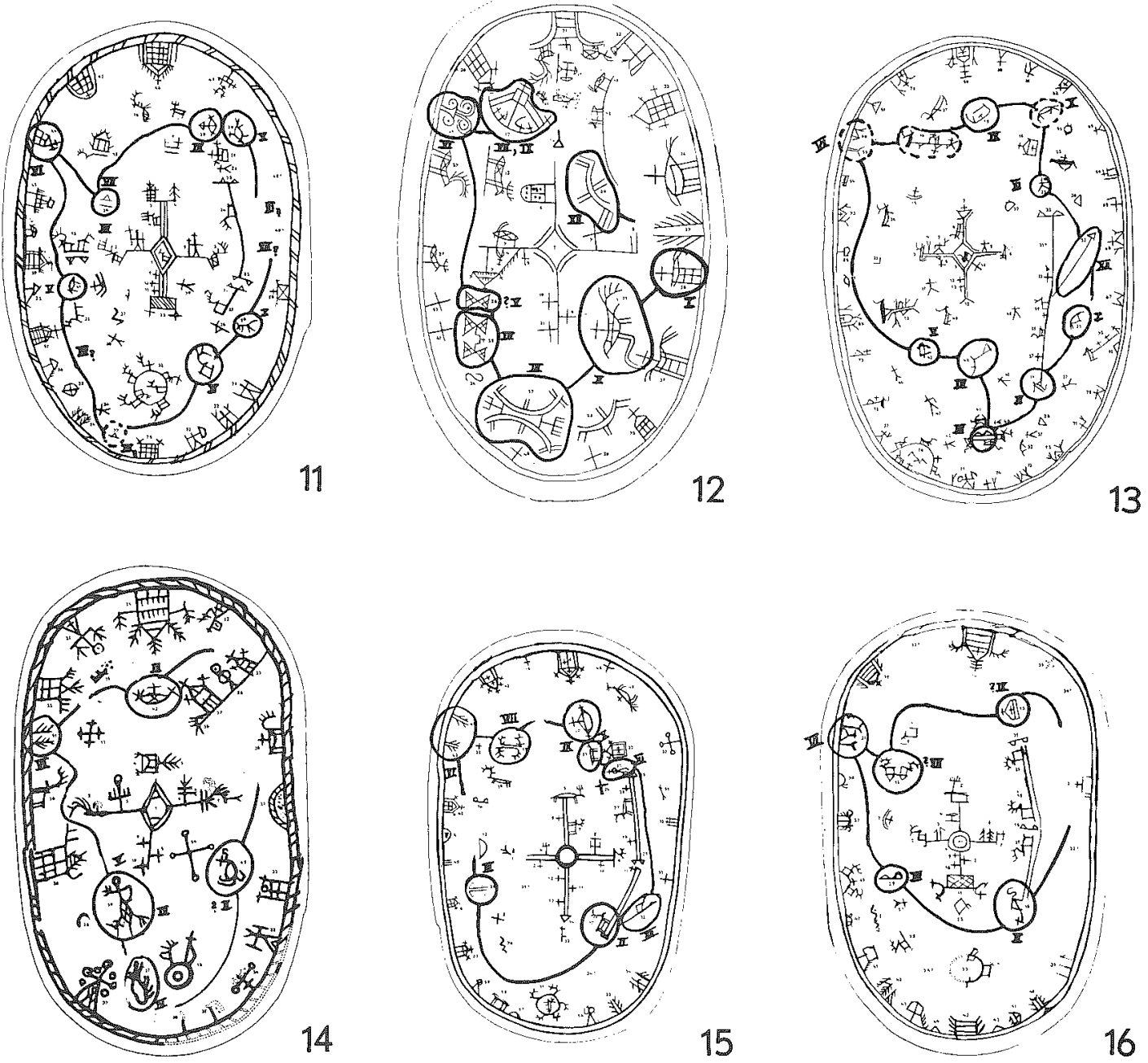

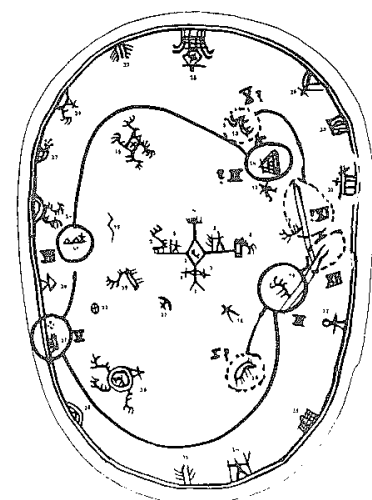

Fig. 14
18
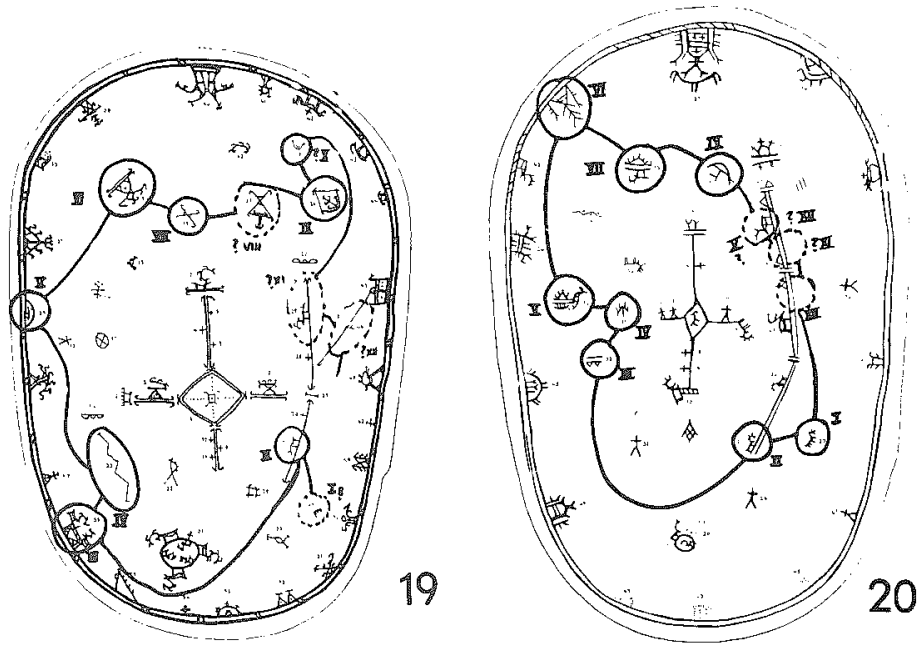

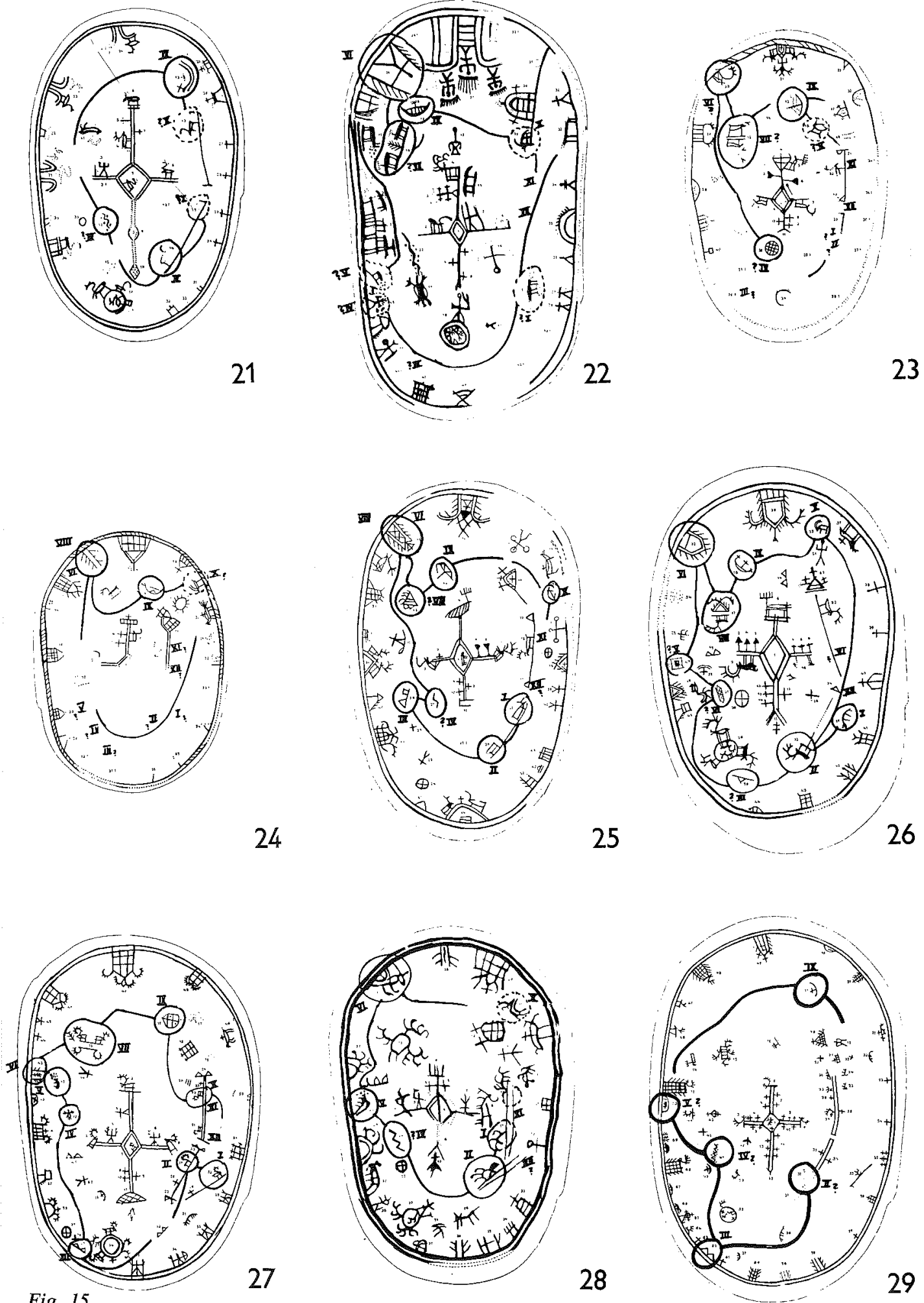

Fig. 15 

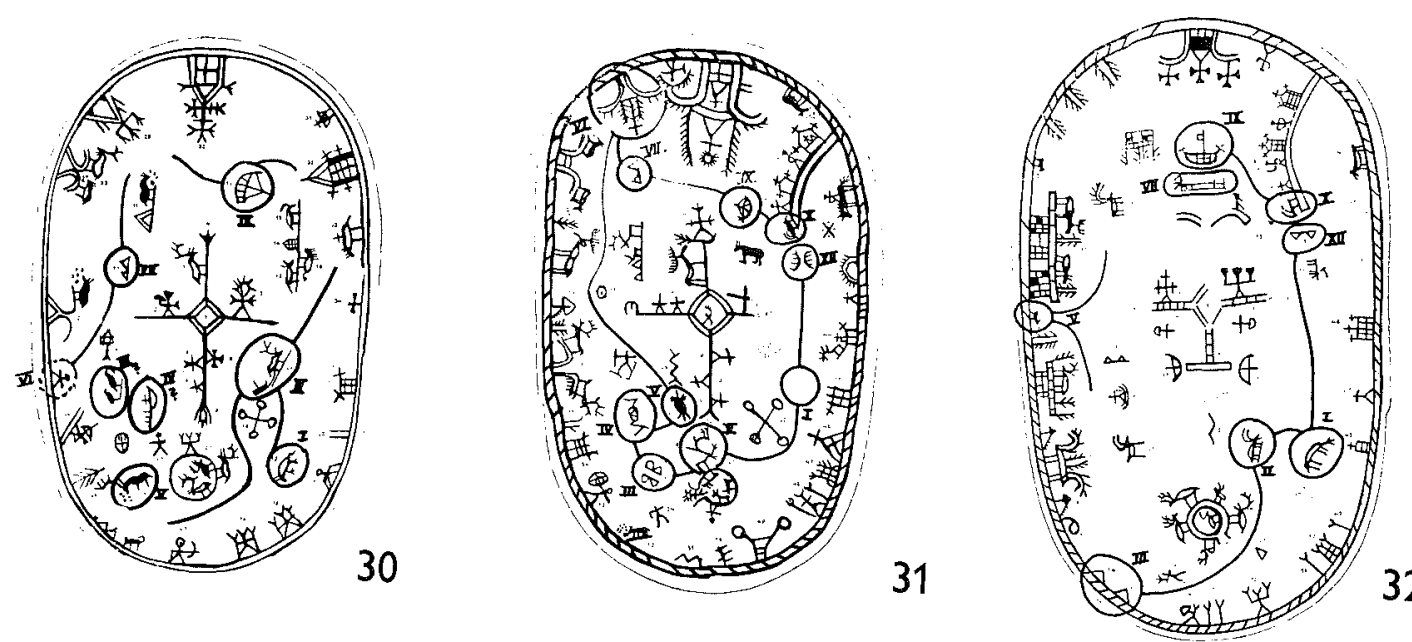

32
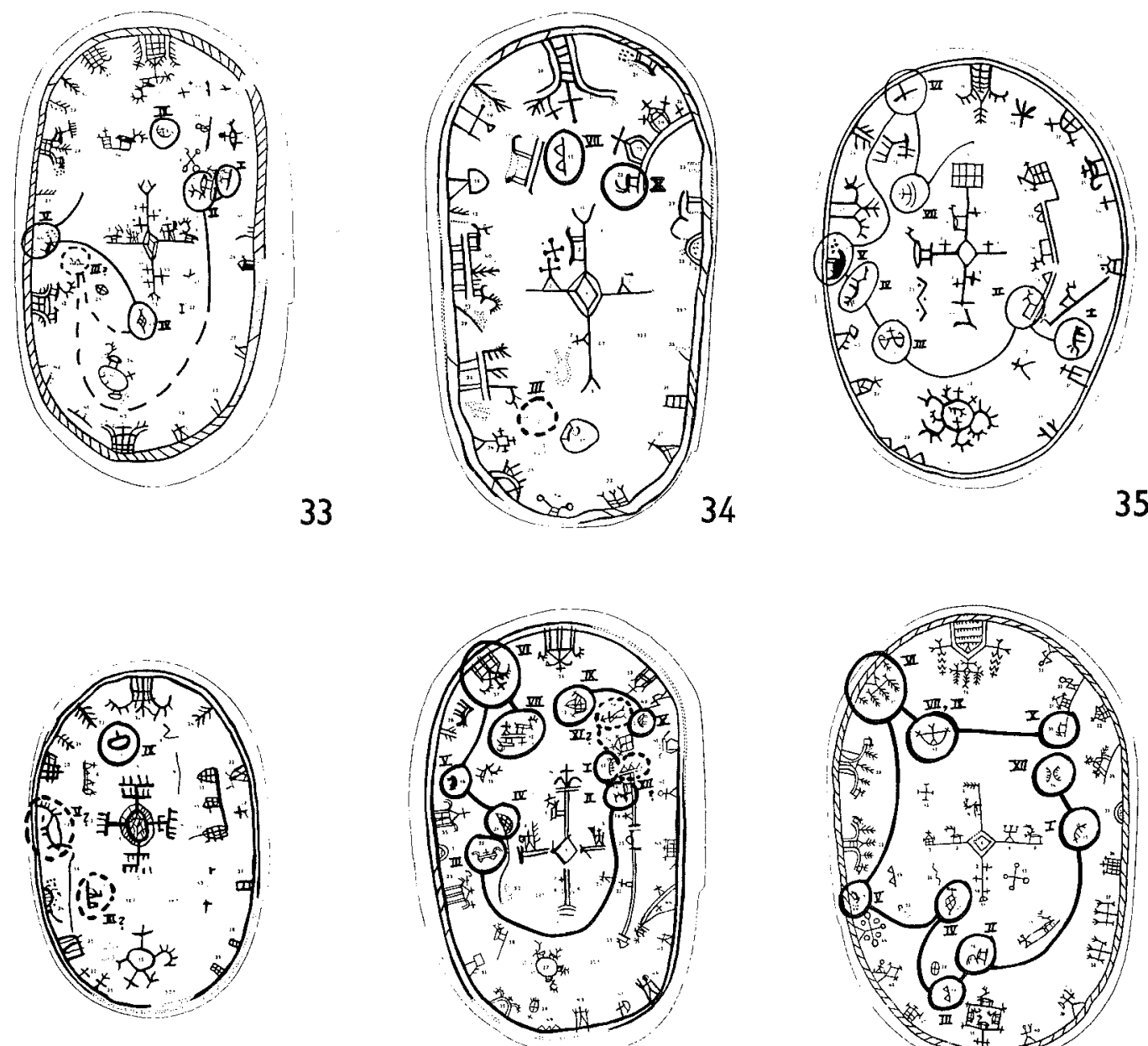

Fig. 16

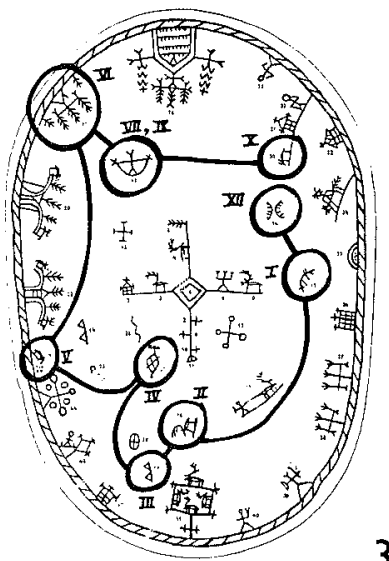



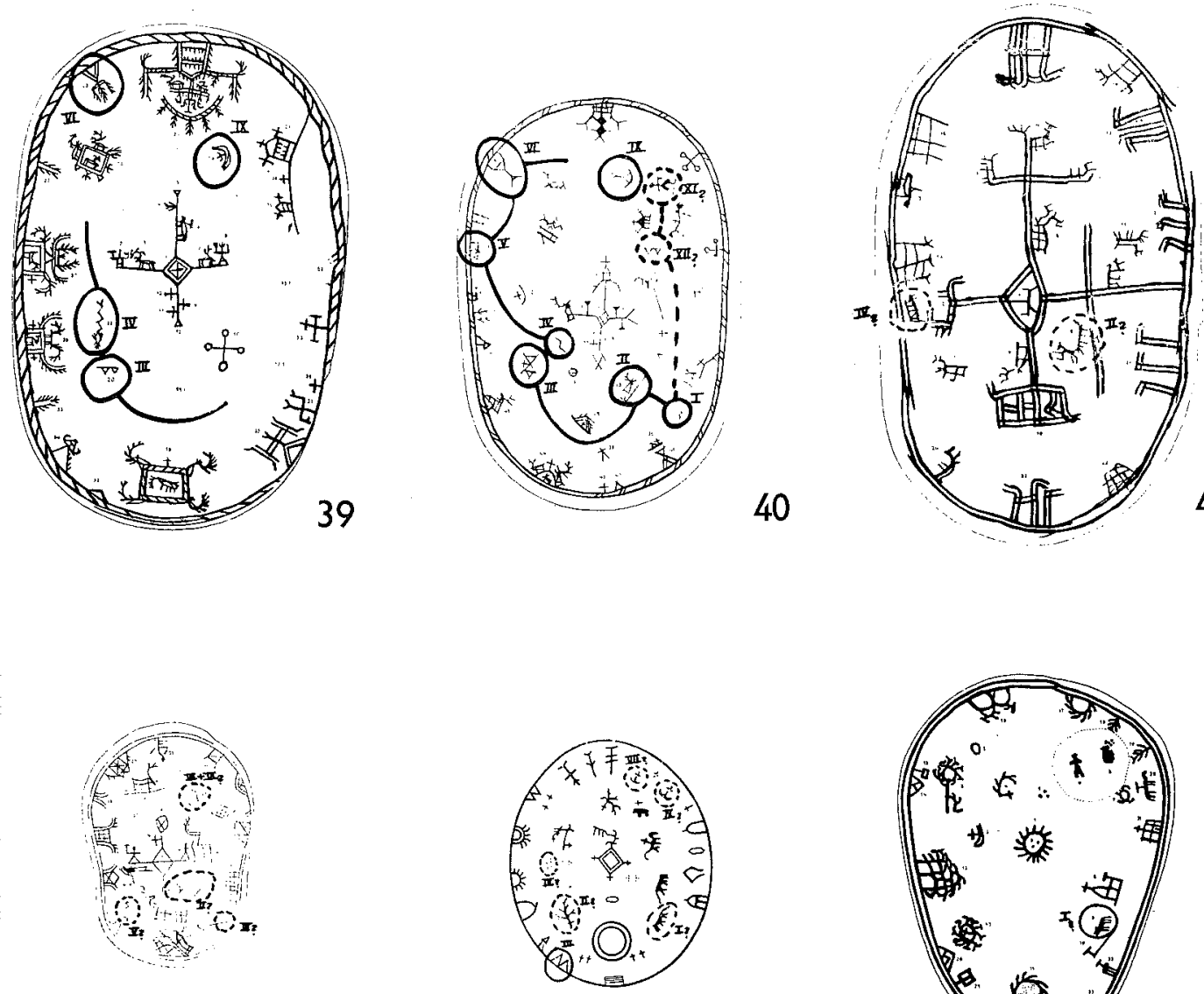

46

154

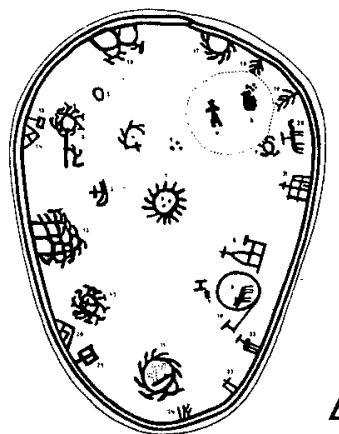

42

Fig. 17. Drum no. 42 added to show a central motif with round sun design.

introduction to my part study "Pointers and clues to some Saami drum problems" published in Arv. With the increasingly richer and more detailed knowledge of the functions of drums and Shamanism in the rest of the world it may be fruitful to devote further study to the Saami drums and their role in Saami religion. It may then transpire that one side effect is an increased "cognitive relativism" as a counterweight to the still dominant "cognicentricity" of the West, to quote the anthropologist Michael Harner. And he continues: "The time may be ripe for unprejudiced analyses of SC with scientific methods and in OC terms"' (Harner 1983, 16. SC=shaman's state of consciousness, $\mathrm{OC}=$ ordinary state of consciousness). $\mathrm{He}$ is beginning to find a response since increasing numbers of academic institutions, generally medical or psychological, are collaborating in experiments with shamans (still mainly in the United States). Shamanistic methods and 

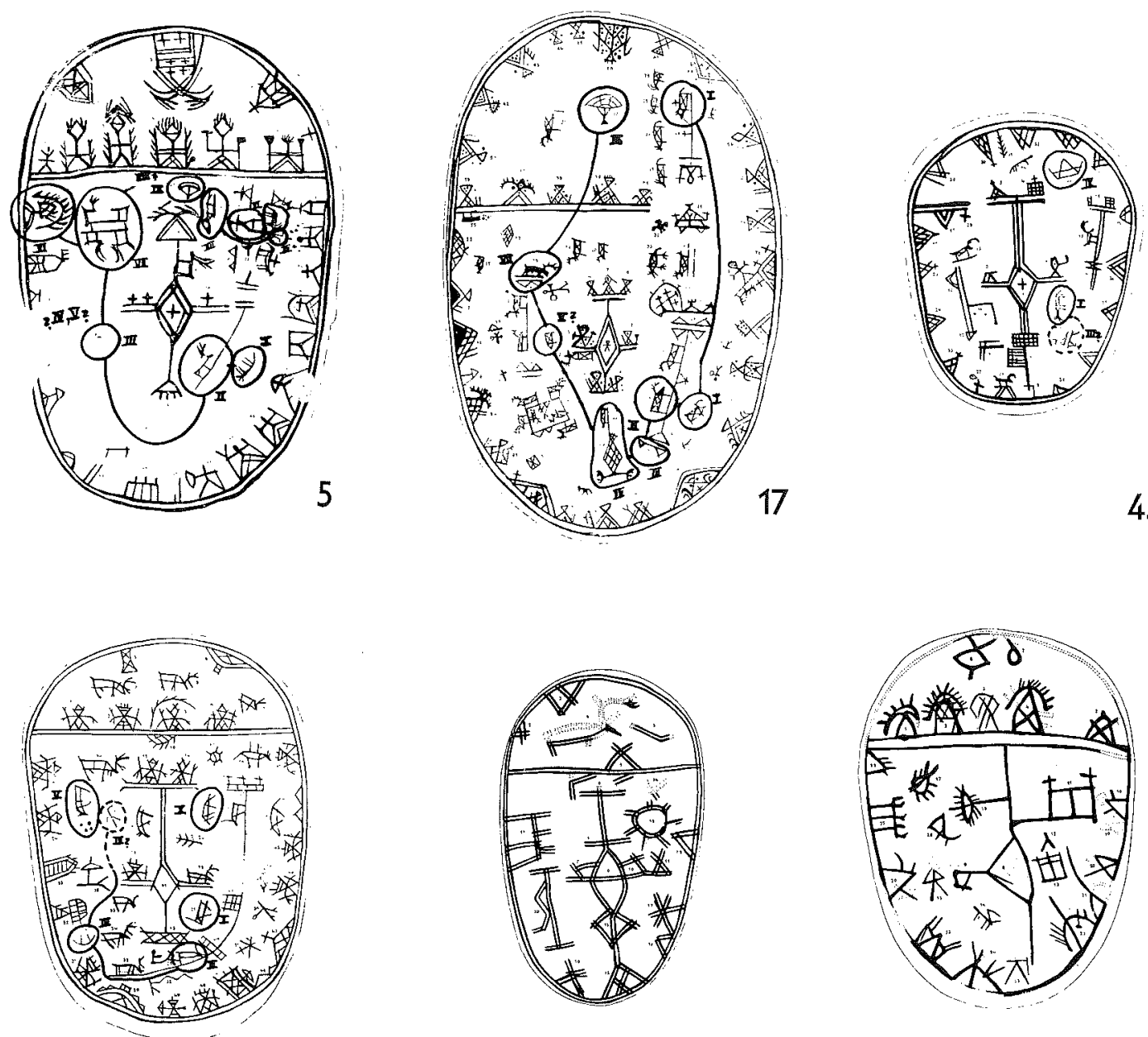

47
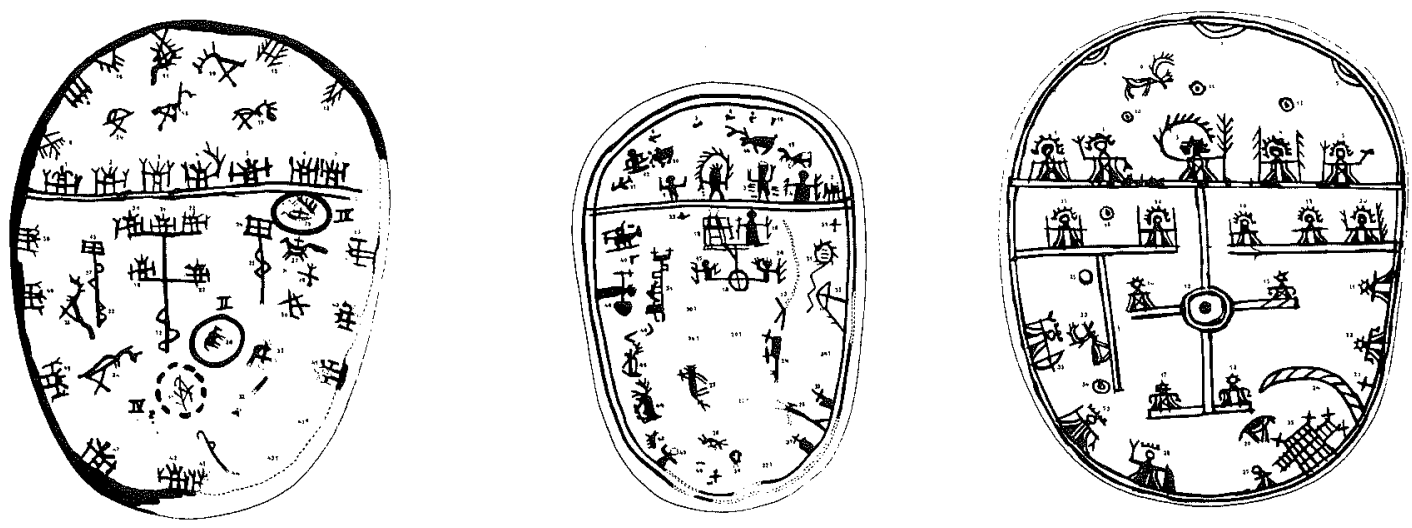

Fig. 18 


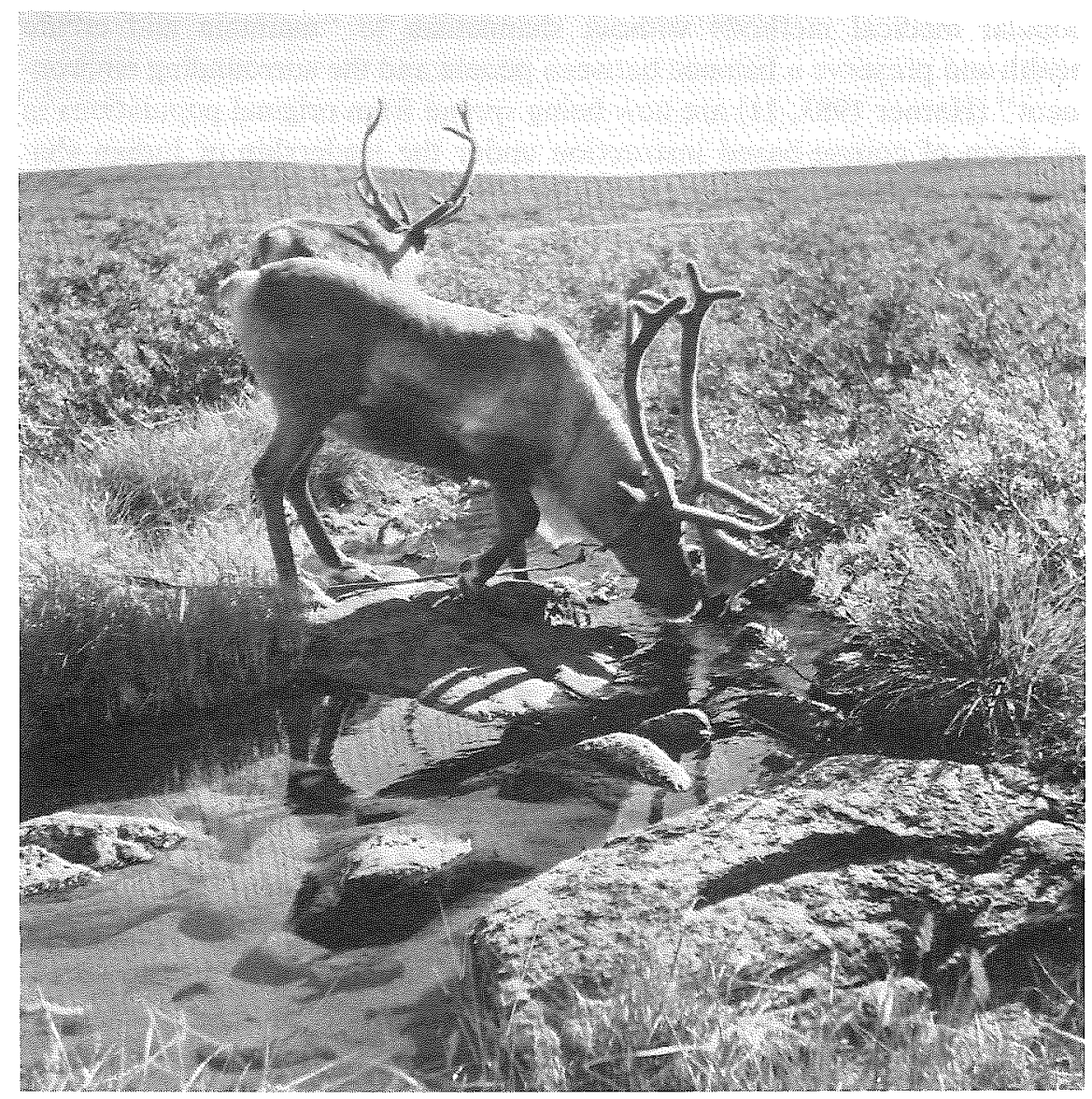

Fig. 19. BOAZOI, reindeer, was the dominant feature of the old Saami nomadic subsistence and culture. This was naturally reflected in the sphere of religion, where the reindeer was the main sacrificial animal, either in complete shape or partially as fat, antlers, etc. The shaman, noai'de, used the skin as drumhead, and made the drumstick and sometimes also the pointer of bone from antlers. The reindeer is frequent among the red-painted figures on the drumskin and is seen in different positions, also in the rhombus of the central cross-design. As sarves, reindeer bull, it served as one of the principal power or guardian spirits of the shaman, sometimes even as his alter ego. When he entered another state of consciousness with the help of drumming, his reindeer vision must have looked as real as in ordinary life. (Author's photo.)

Fig. 18. Drums with combined vertical and horizontal world perspectives, with or without recognizable influences from zodiacal concepts. 
popular medical methods without shamanism to "maintain and create health and preserve a balance between people and the surrounding environment" (Harner 1983, 11) are now being spread from original populations in the form of course-based instruction under the leadership of Indian shamans, or similar people (see e.g. Gruber 1985), with the help amongst other things of psychocosmograms. These are more or less based on the traditional Indian "medicine wheels", which were included in the Sun Dance system of the prairie Indians (e.g. Hultkrantz 1973; Storm 1972, 4 ff.). Such ethnoastronomically related aids may perhaps provide an impulse for deeper study of our unfortunately so fragmentary picture of the experiences of the Saami noai'des. The little we know about Saami SC has recently been considered by Louise Bäckman, who reproduces details from a couple of extant descriptions of "soul-journeys", one from the 17th century (by Nicolaus Lundius), another from recent tradition (through Lars Pirak; Bäckman 1982, 125f.). Both accounts are in complete agreement with shamanic "journeys" in a state of trance, even a light one, according to Harner's descriptions (Harner 1983, e.g. 73) and with the experiences which participants in his courses in Shamanism for westerners have obtained in a trance-like state caused by the effects of drumming, song and dance. Relevant to these "journeys" into the subconscious is the fact that perception is heightened, that egoconsciousness is present the whole time and ensures that the programme for the journey which the shaman has prescribed is carried out. The purpose is generally to strengthen one's own and other People's life force, amongst other things with the help of socalled power animals (with which one can become one), to cure sickness by fighting against the "virus" spirits, to increase one's knowledge of e.g. medical plants and to predict events (Harner 1983, inter alia).

Finally, the relatively new scholarly alignment, known as archaeo-astronomy, should be included as an alternative for enriching our knowledge of Saami religion and shamanism. In 1973 Elizabeth Chesley Baity provided a first comprehensive survey of this interdiscipline, and equated it with the similarly merging and comparable alignment "ethnoastronomy". Since then, much has happened in both respects in different parts of the world, but where the Saamis are concerned, it remains to prepare a plan of action as a basis for systematic inventories in the Saami areas. Experiences from prehistoric stone settings, for example, in the forms i.a. of rings, cairns, stone blocks as landmarks for calendars, can also prove relevant in the Saami areas-in any case the possibilities should be tested. In addition, one can perhaps obtain ideas from studies of e.g. the so-called medicine wheels of prairie Indians, a form of stone ring which, like the drum, can take one far into another reality: a reality which is increasingly beginning to lend 
itself to descriptions in terms of the humanities and the natural and social sciences in an interdisciplinary manner.

\section{Bibliography}

Alstadius, P. 1750. Astrophysica Lapponica. Lärda Tidningar 4. 6.

Apianus, P. 1540. Astronomicum Caesarum. (Facsimile ed. 1979.) See also Wattenberg.

Bäckman, L. 1975. Sáiva. (Stockholm Studies in Comparative Religion 13.) Stockholm. [English summary: Sájva-conceptions of guardian spirits among the Lapps.]

- 1982. The noajdie and his ecstasy. Religious ecstasy. Ed. by N. G. Holm. (Scripta Instituti Donneriani Aboensis 11.) Stockholm.

Baity, E. C. 1973. Archaeoastronomy and ethnoastronomy so far. Current Anthropology 14, 4.

Branston, B. 1980. Gods of the North. London.

Cook, R. 1974. The Tree of Life. London.

Champeaux, G. de \& Sterckx, S. 1966. Introduction au monde des symboles. Zodiaque 3.

Edsman, C.-M. 1957. Den dansande solen. Religion and Bibel 16.

Eliade, M. 1964. Shamanism. New York.

Granlund, I. \& Granlund, J. 1973. Lapska ben- och träkalendrar. (Acta Lapponica 19.) Stockholm.

Gruber, E. 1985. Traum, Trance und Tod. Breisgau.

Halifax, J. 1982. Shaman. London.

Hall, E. T. 1977. Beyond culture. New York.

Harner, M. 1980. The way of the shaman. San Francisco.

- 1983. Shamanens väg. Göteborg.

Hedvall, B. Astrokarta E. Göteborg.

Hellbom, A.-B. 1984. Huicholernas världsbild. Shamanen som konstnär. Stockholm.

Hultkrantz, A. 1973. A definition of shamanism. Temenos 9.

- 1979. The traditional symbolism of the Sun Dance Lodge among the Wind River Shoshoni, Religious symbols and their functions. Ed. by H. Biezais. (Scripta Instituti Donneriani Aboensis 10.) Stockholm.

- 1985. The shaman and the medicine-man. Social Science Medicine 20, 5.

Jankovics, J. 1984. Cosmic models and Siberian Shaman drums. Shamanism in Eurasia. Ed. by M. Hoppál. Göttingen.

Jansson, S. O. 1974. Lapska kalendrar. Rig.

Karsten, R. 1952. Samefolkets religion. Helsingfors.

Kenton, W. 1974. Astrology. London.

Lommel, A. 1985. Schamanismus in Eurasien. Anthropos 80.

Lundmark, B. 1982. Baei'vi mánno nástit. (Acta Bothniensia Occidentalis 5.) Umeå.

Manker, E. 1938. Die lappische Zaubertrommel 1. (Acta Lapponica 1.) Stockholm.

- 1947. De svenska fjällapparna. Stockholm.

- 1950. Die lappische Zaubertrommel 2. (Acta Lapponica 6.) Stockholm.

Mann, A. T. 1979. The round art. New York. 
Mansfield, V. N. 1981. Mandalas and Mesoamerican pecked circles. Current Anthropology 22, 3 .

Mason, B. S. 1938. Drums, tomtoms and rattles. New York.

Mebius, H. 1968. Värrō. (Skrifter utgivna av Religionshistoriska institutionen i Uppsala, Hum. fak., 5.) Uppsala.

Negrin, J. 1984. Från nierika till garnmålning. Shamanen som konstnär. Stockholm.

Orion. 1982. Encyclopaedia Britannica VII. Chicago ...

Pettersson, O. P. 1979. Kristoffer Sjulssons minnen. Ed. by L. Bäckman \& R. Kjellström. (Acta Lapponica 20.) Lund.

Pirak, A. 1937. En nomad och hans liv. Stockholm.

Reuterskiöld, E. 1910. Källskrifter till lapparnas mytologi. (Bidrag till vår odlings häfder 10.) Stockholm.

- 1928. Från guldhornen till lapptrumman. Festskrift til Rektor J. Qvigstad. (Troms $\varnothing$ museums skrifter 2.) Oslo.

Ridington, R. \& Ridington, T. 1970. The inner eye of shamanism and totemism. History of religions 10 .

Schefferus, J. 1956. Lappland. [Ed. by] E. Manker et al. (Acta Lapponica 8.) Stockholm.

Schwabe, J. 1951. Archetyp und Tierkreis. Basel.

Sommarström, B. 1965. Skafttrumma från Lule lappmark. Norrbotten.

- 1967. Den fyrkantiga solen. Norrbotten.

- 1969. Die Grifftrommel aus Lule Lappmark. Ethnos.

- 1985. Pointers and clues to some Samii drum problems. Saami Pre-Christian religion. Ed. by L. Bäckman \& $\AA$. Hultkrantz. (Stockholm Studies in Comparative Religion 25.) Stockholm. Also in Arv 1983.

Storm, H. 1972. Seven arrows. New York ...

Turi, J. 1910. Muittalus samid birra. /Ed. by/ E. Demant. Stockholm.

Von Del Chamberlain. 1982. When stars came down to earth. Los Altos, CA.

Wattenberg, D. 1979. Peter Apianus and Astronomicum Caesarum. (see P. Apianus above). Leipzig. 